\title{
Analysis of Stress, Strain, and Fatigue Strength of the Rotary Table of Boom-type Roadheaders
}

Jie Tian ( $\square$ tianj@cumtb.edu.cn )

China University of Mining and Technology https://orcid.org/0000-0003-2224-3428

lansheng zhang

Shijiazhuang coal machinery company

haifeng yao

Shijiazhuang coal machinery company

miao Wu

China University of Mining and Technology,beijing

Research

Keywords: Fatigue strength, Modal analysis, Rotary table, Strain, Stress

Posted Date: August 4th, 2020

DOI: https://doi.org/10.21203/rs.3.rs-49993/v1

License: (c) (i) This work is licensed under a Creative Commons Attribution 4.0 International License. Read Full License 


\title{
Analysis of stress, strain, and fatigue strength of the rotary
}

\section{table of boom-type roadheaders}

\author{
Jie Tian ${ }^{1},{ }^{*}$ - Lansheng Zhang², Haifeng Yao ${ }^{1}$, Miao Wu${ }^{1}$ \\ ${ }^{1}$ School of Mechanical Electronic and Information Engineering, China University of Mining and \\ Technology (Beijing), Beijing 100083, China \\ ${ }^{2}$ Shijiazhuang Coal Mining Machinery Company Limited, Shijiazhuang 051431, China
}

\begin{abstract}
The rotary table is the key component in the optimal design of roadheaders. In this study, a simulation model of the cutting part and a rotary table is established in SolidWorks, and stress analysis and strength evaluation of the structure of the rotary table are performed. To this end, finite element analysis is performed on the basis of the dynamic theory of a coupled multibody system comprising rigid and flexible bodies. Considering actual working conditions, the load file of the cutting head is calculated based on the development of the "Roadheader Machine load Calculation Program", and the stress and strain cloud map of the cutting head running to the bottom left, middle end, and right end of the rotary table is obtained through Adams simulation. Then, the 6-order modal analysis is carried out, and the $S$ - $N$ curve of the turntable is finally established. In addition, the fatigue life reliability of the turntable is analyzed using the AWE fatigue module. The results show that, provided reliable working conditions, the EBZ160 type roadheader machine during the normal service life shows no risk of fatigue failure under normal working load.
\end{abstract}

Keywords: Fatigue strength, Modal analysis, Rotary table, Strain, Stress

Highlights:

- A simulation model of the cutting part and rotary table is established.

- Load stress and strain of the rotary table of a roadheader machine were studied.

- Modal analysis of the rotary table in the free state was performed.

- Dynamic characteristics of the roadheader agree with the rotary table strength.

- Under normal working conditions, EBZ160 roadheader is not prone to fatigue failure.

\section{INTRODUCTION}

Roadheaders are mechanized excavation equipment that have secured an exceptional place among other excavation machines. As a key component, rotary tables affect the overall performance of roadheaders. In the process of cutting coal, the rotary table is subjected to not only the force generated by the rotary hydraulic cylinder, rotary bearings, and lifting hydraulic cylinder, but also all kinds of working loads transmitted through the cutting arm [1]. Insufficient stiffness and strength of the local structure of the rotary table will reduce the overall working performance of the roadheader, resulting in decreased load capacity of the whole machine. Therefore, the rationality of the structure design of the rotary table will affect the reliability and working performance of the roadheader. Accordingly, it is necessary to analyze the stress, strain, and fatigue of the rotary table.

During the last decades, in order to ensure the efficiency and dynamic reliability of roadheader machines, several scholars from China and abroad have performed relevant research. The representative results of this field of research are as follows: abroad, these studies mainly focused 
on auxiliary cutting assistances, new cutting-head designs, developing performance prediction models, artificial Neural Network (ANN) techniques, cutting tools, and addition of control systems to roadheaders.

In Ref. [2], the stability of roadheaders with mini disc cutters in different cutting modes and roadheaders equipped with classic point attack cutters are analyzed, compared, and discussed. In Ref. [3], an algorithm for computer simulated operation of an automatic cutting head rotational speed control system with a PID controller was addressed. The computer simulations enabled the assessment of the operational efficiency of the proposed automatic control system in regard to reducing energy consumption when cutting hard rocks. In Ref.[4], Genetic programming (GP) and gene expression programming (GEP) techniques were applied to yield more accurate models for predicting the performance of roadheaders. In Refs. [5,6], artificial neural network (ANN) techniques for predicting of the instantaneous cutting rate (ICR) of roadheaders were used, and a mathematical model was developed in the Matlab/Simulink environment. In Ref. [7], the established simulation model allows numerical investigations, particularly for optimizing the values of the cutting process parameters, including the selection of cutting head angular speed from the aspect of reducing dynamic loads and minimizing the energy consumption during the cutting process. In Ref. [8], the methodologies of several pick cutters were designed through multi-body dynamics analysis. Further, the grinding efficiency of the designed pick cutter arrangement was studied for sumping and shearing cutting works through boom motions of the excavator.

Nevertheless, most of the studies focused on the performance of the whole machine, and the stress, strain and fatigue analyses of the rotary table have rarely been performed.

In China, several studies performed fatigue life reliability analysis and performance prediction of turntables using Adams software and the reliability theory. UG and MATLAB software were used to optimize the design and mechanical properties of the EBZ300 type longitudinal shaft roadheader machine and the EBH360 type transverse horizontal roadheader machine rotary table [9-15]. The finite element analysis of the rotary table of the EBH350 roadheader machine based on ANSYS Chunhua was carried out in Ref. [16]. The vibration of a roadheader rotary table based on the finite element method using data from an underground coalmine was analyzed in Ref. [17].

Based on this, the China University of Mining and Technology (Beijing) and Shijiazhuang Coal Mining Machinery Company Limited cooperated to study the reliability of a tunneling machine. For this purpose, the stress, strain and fatigue strength analysis of the rotary table of the tunneling machine were conducted.

\section{ROTARY STRUCTURE}

The body part of the roadheader machine is in the center of the body, and it is the main frame of the roadheader, welded by a high-quality steel plate. The main body of the roadheader includes components, such as the rotary table, rotary bearing, rotary hydraulic cylinder, and main frame, as shown in Figure 1. The rotary table can swing left and right relative to the rack under the action of two rotary hydraulic cylinders. The rear support part is connected to the host frame by M24 bolts. The roadheader machine features a combination of the cutting mechanism, shipping mechanism, walking mechanism, and other major implementing mechanisms.

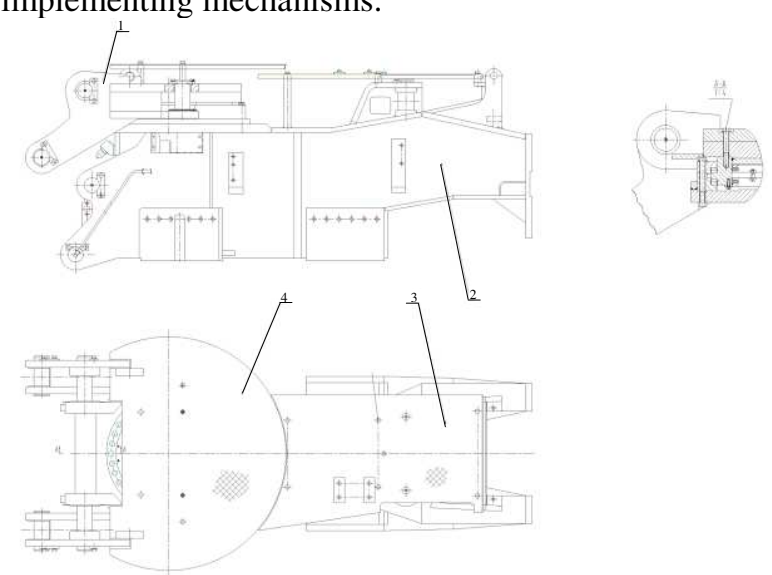

Fig.1. Body part (main frame)

1. Rotary table, 2.Body part, 3. Upper cover plate, 4. Lower cover plate

The rotary table mainly plays the role of supporting the cutting arm and connecting the main frame. In the design optimization of the roadheader, the rotary table is one of the most important parts. As mentioned earlier, the rotary table is subjected to complex forces and bears a large load. When the cutting head drills into coal, 
cutting arm lifting and rotary cutting, radial and axial load, and tilt flip moment are produced, and they pass through the rotary table to the main body frame. In addition, the rotary table is a large casting with coarse grains that is prone to cracking, deformation, shrinkage, and other defects. Therefore, the performance of the rotary table will determine the stability and efficiency of the roadheader machine [18][19]. Improving the working performance and working life of the roadheader is very important. For this purpose, the finite element analysis serves as a useful tool for analyzing stress and evaluating the strength of the rotary table structure. In this work, the working principle, and design characteristics of the rotary are analyzed, and force analysis is performed.

The main research object is the EBZ160 type tunneling machine rotary table, which has a pushpull hydraulic cylinder rotary mechanism. The mechanism is implemented by the seat method. The mesh structure of the rotary is shown in Figure 2.

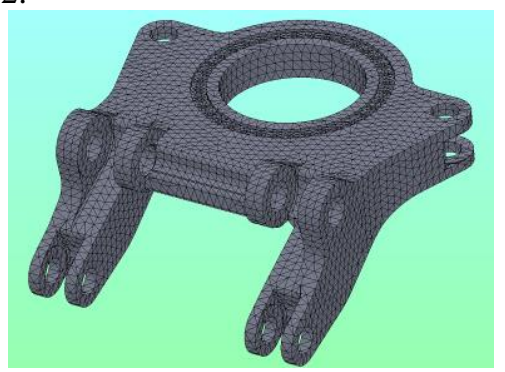

Fig.2. Mesh of the rotary table

There are 6 sets of joint holes in the main body of the rotary structure, which connect the lifting hydraulic cylinder, the rotary hydraulic cylinder, and the connecting cutting part of the cutting part. The rotary table and the inner ring of the rotary support are connected by the pin shaft through the hole distributed along the circumference to realize the connection between the rotary table and the body frame of the roadheader. The rotary table has several advantages as follows: the relative structure of the rotary mechanism is simple, the height of the hydraulic cylinder can be adjusted properly, assembly precision requirements are low, the work is stable, the life is long, and maintenance change is easy.

\section{ANALYSIS OF LOAD STRESS AND STRAIN}

Because the actual load of the roadheader depends on the seam section of the roadway or the hardness of the rock, sufficient strength and stiffness of the main bearing components of the roadheader machine is required when rating the pressure of the hydraulic system. Therefore, the research and analysis of the cutting part and the rotary in this study are based on the process of cutting the roadway according to the technology that affords the maximum output state of the hydraulic system.

\subsection{Dynamic simulation model of the cutting part and rotary table}

Static and modal analyses of the rotary were carried out to ensure that the strength and stiffness of the rotary are sufficient during the working process and that no resonance is generated under the action of external loads. A virtual prototype dynamics simulation model of the cutting part and rotary table was established using automatic dynamic analysis of the mechanical systems simulation environment. The rotary table was accurately modeled, and other components, such as the hydraulic cylinder, cutting part, rotary pin shaft, and rotary support, were simplified, but their accuracies were maintained. The overall simulation model was set to a zero-gravity state, and the reaction force of the rock to the cutting head and the self-weight of the cutting part were added to the cutting part in the form of load [20].

\subsection{Stress and strain analysis of rotary table}

The roadheader machine was designed using the bottom-up approach, from the left and right of the class S-type cut path. Therefore, according to the calculation of the program in Ref. [21,22], the swing angle of the rotary and the change curve of the lifting angle of the cutting part can be cut along the path, as shown in Figure 3. Force analysis and static finite element analysis of the rotary table were carried out by selecting three groups at the left and right ends of the bottom, middle, and upper segments of the cutting head. 


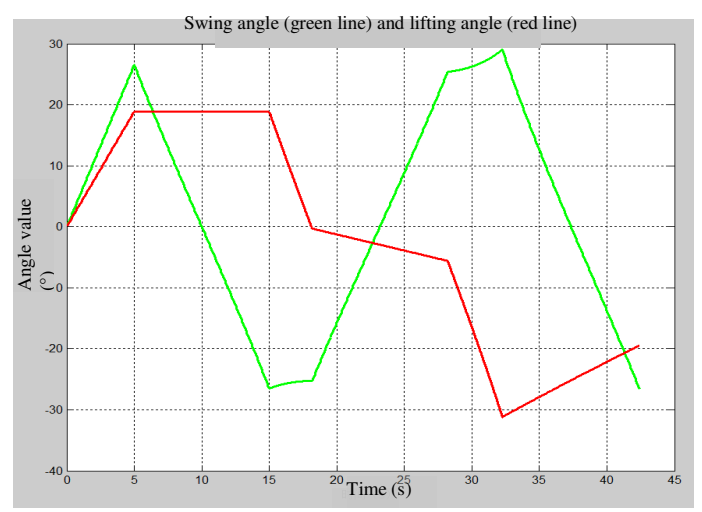

Fig.3. Swing angle and lifting angle curve for a roadheader cut by path

The constraints of the rotary table were derived from the slewing support and two rotary pin shafts, and the load was directly derived from the cutting motor and the pins of the lifting hydraulic cylinder and the rotary hinge. The load transmitted by the pin shaft depends on the weight of the cutting part and the reaction force of the rock to the cutting head. In order to accurately calculate the force of the cutting part and the hydraulic cylinder on the rotary during the lifting and cutting process, a simulation model of the virtual prototype of the lifting and cutting process needs to be established. The model used in this study is shown in Figure 4.

The force of the rock on the cutting head is calculated according to the maximum output capacity of the roadheader machine. Thus, the maximum output extrusion crushing force calculated earlier is the maximum reaction of the rock to the cutting head, and the maximum output crushing force calculated during the lifting and cutting process was imported into ADAMS. Based on the dynamic theory of the rigid and flexible coupled multi-body system, the stress condition at each hinge point caused by the individual lifting and cutting process is shown in Figure 5. Detailed parameters of each force obtained from the simulation were derived and the force direction was adjusted uniformly to coincide with the previously defined roadway space coordinates. The force curves of each hinge contact are shown in Figure 6.

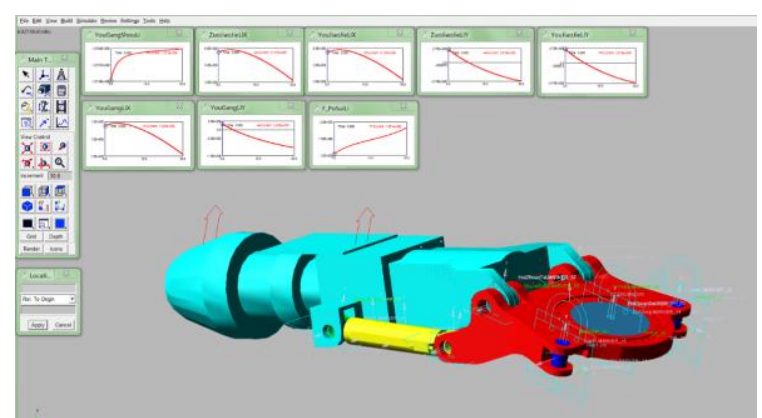

Fig.4. Virtual simulation model for cutting part and rotary table during the lifting and cutting process

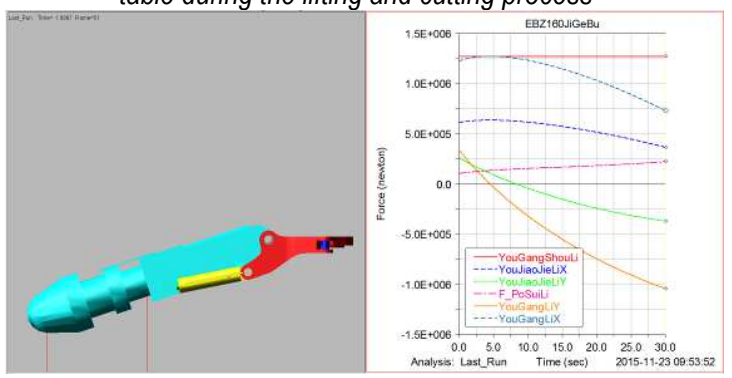

Fig.5. Stress state of each hinge joint when the cutting head cuts from bottom to top

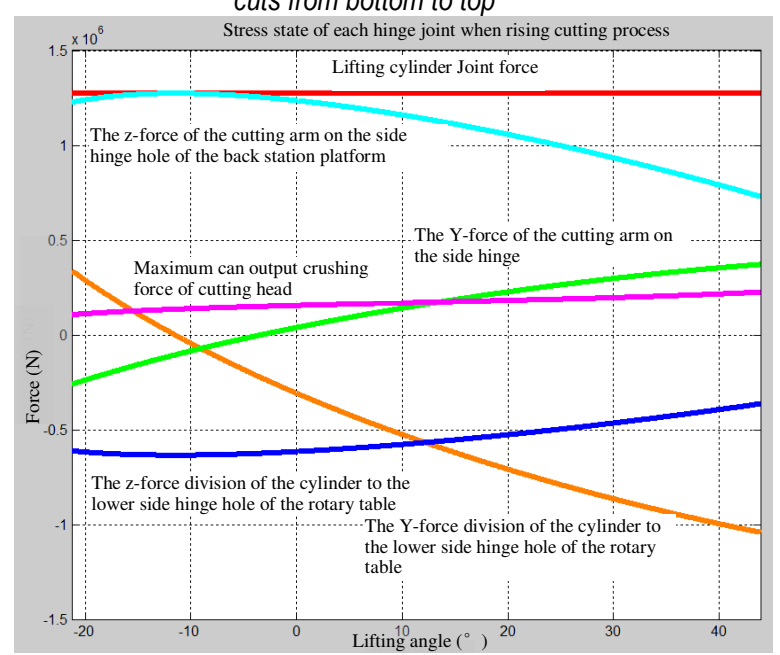

Fig.6. Stress state of each hinge joint during lifting and cutting after adjustment

Static analysis of the rotary table was performed using the nonlinear mode. A custom mode was selected for the material; the elastic modulus was set to $210 \mathrm{GPa}$, Poisson's ratio was set to 0.3 , the yield limit was set to $510 \mathrm{MPa}$, the effects of the rotary hydraulic cylinder and slewing support on the rotary were replaced by the corresponding constraints, the inner cylindrical surface of the rotary with concentric support was selected (4 cylindrical surfaces in contact with the rotary pin shaft), and the unit 
nodes on these cylindrical surfaces were set to axial and radial displacement of 0 . According to the load of the rotary at the left end of the lower part of the cutting head, the load was added to the cylindrical surface in the upper and lower hinge holes of the rotary table. Transverse resistance of the cutting head and cutting resistance of the truncated tooth were added in the form of remote load, using the standard mesh partition unit, and the Jacobian error was set to $2 \mathrm{~mm}$. The average size of the whole unit was $40 \mathrm{~mm}$.

Because of the similar analysis ideas and the means used, this study mainly expounds the stress and strain of the rotary at the left most end of the bottom section.

The finite element analysis model for the cutting head at the left end of the lower segment is shown in Figure 7. The stress cloud diagram was generated when the cutting head was at the left end of the lower section, as shown in Figure 8 (a). The overall stress value of the rotary was small, but the stress value inside the hinge ear of the rotary and the cutting part was larger, reaching $509.994 \mathrm{MPa}$, which is close to the material yield limit. Nevertheless, this corresponded to a small local area. Figure 8 (b) shows an area where the stress value exceeds 400 $\mathrm{MPa}$. Figure 8 (c) is a combined displacement cloud map with maximum displacement values of $1.45-0.643 \mathrm{~mm}$ in the $X$ direction, $1.297 \mathrm{~mm}$ in the $\mathrm{Y}$ direction, and $-0.458 \mathrm{~mm}$ in the $\mathrm{Z}$ direction. All these values were observed on the left lifting hydraulic cylinder and the hinge ear of the rotary table.

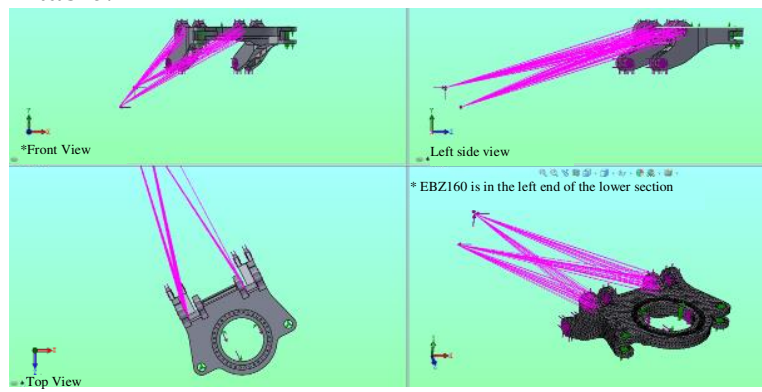

Fig.7. Finite element analysis model for the cutting head in the left end of the lower section

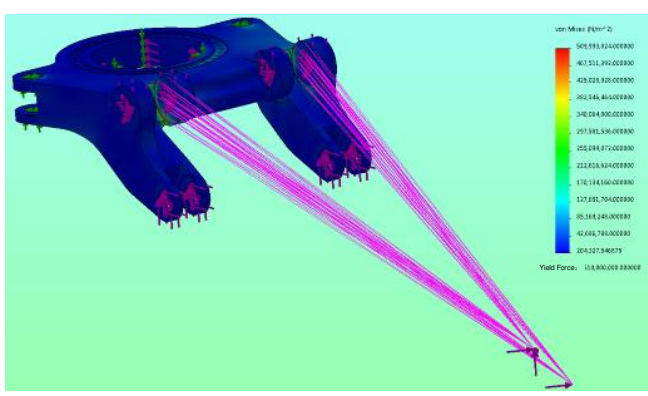

a) Stress Cloud Diagram

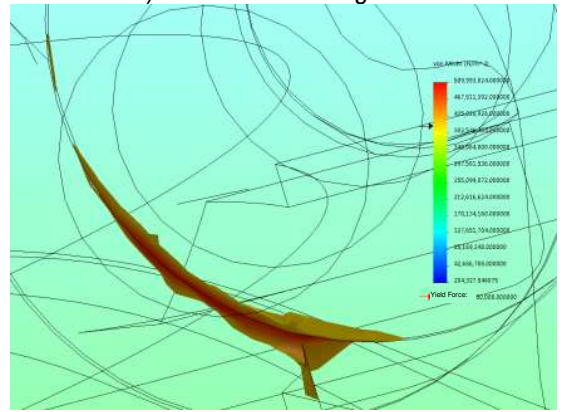

b) Stress value exceeds area cloud map

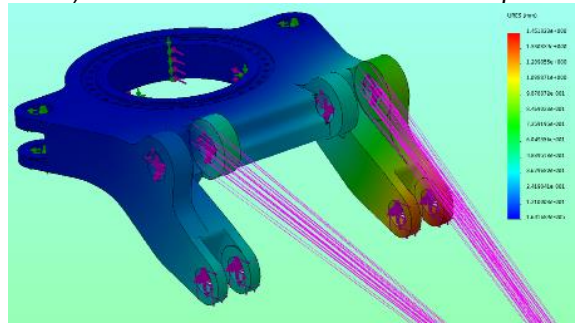

c) Combined Displacement Cloud Map

Fig.8. Stress cloud for the cutting head in the left end of the lower section

The stress cloud map of the rotary table was studied when the cutting head was at the bottom, middle, and upper far left. By synthesizing the results of the three groups, we found that in the process of cutting by path, the stress of the rotary table reaches close to the yield limit when all kinds of output were at their maximum values. Furthermore, the maximum dynamic characteristics of the whole machine agreed well with the structure strength of the rotary table. The yield limit was very small, and thus no damage to the rotary can be expected. In real underground production processes, the final load of the cutting part will generally reach only $50 \%$ to $60 \%$ of the maximum output. Thus, the strength and stiffness of the rotary are sufficient.

\section{MODAL ANALYSIS OF ROTARY TABLE}

The modal analysis of the rotary in the free state was carried out, and the 6-order modal 
modes obtained in the rotary table are shown in Figure 9.

(1) The natural frequency of the 1 st order mode was $170.19 \mathrm{~Hz}$, and the mode of vibration was staggered by the outstretched arm on the left and right sides. In addition, the oscillation amplitude was large at the front and rear, and the swing amplitude was small.

(2) The natural frequency of the 2 nd order mode was $173.44 \mathrm{~Hz}$. The outstretched arm on the left and right sides swung at the same time. The swing amplitude was large at the front and rear and small at the right and left.

(3) The natural frequency of the 3rd order mode was $351.59 \mathrm{~Hz}$. The outstretched arms of the left and right sides swung at the same time in a symmetrical manner. The front and rear swing amplitudes were very small, and the left and right swing amplitudes were relatively large.

(4) The natural frequency of the 4th order mode was $355.91 \mathrm{~Hz}$. The outstretched arms of the left and right sides swung at the same time. The front and rear swing amplitudes were very small, and the left and right swing amplitudes were relatively large.

(5) The 5th-order modal natural frequency was $571.6 \mathrm{~Hz}$. The outstretched arms of the left and right sides swung symmetrically at the same time. The front and rear swing amplitudes were small, and the left and right swing amplitudes were relatively large. The swing was slightly distorted, driven towards the side of the rotary. The cutting part of the hinge of the inner part swung up and down.

(6) The 6th-order modal natural frequency was $643.92 \mathrm{~Hz}$. The left and right sides of the outstretched arm swung at the same time. The front and rear swing amplitudes were small., and the left and right swing amplitudes were larger. The oscillation of swing increased, and it was driven towards the side of the rotary. The cutting part of the hinge of the two inner hinges and the inner part swung up and down.

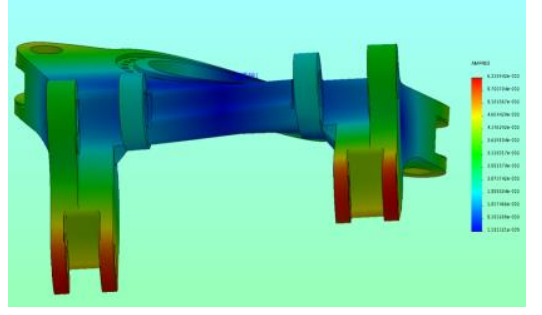

a) I-Order

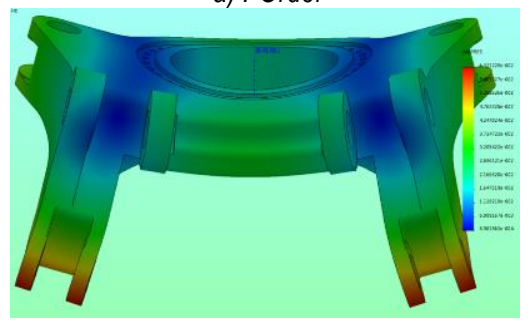

b) II-Order

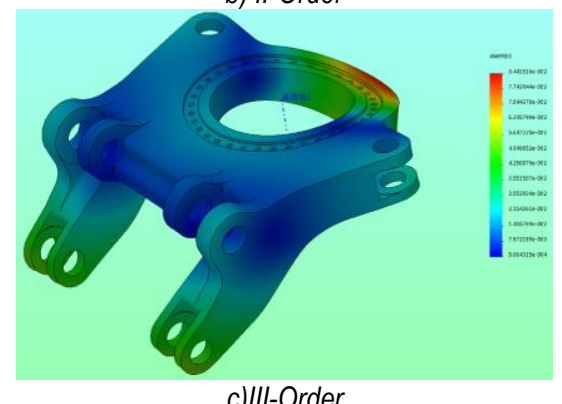

c)III-Order

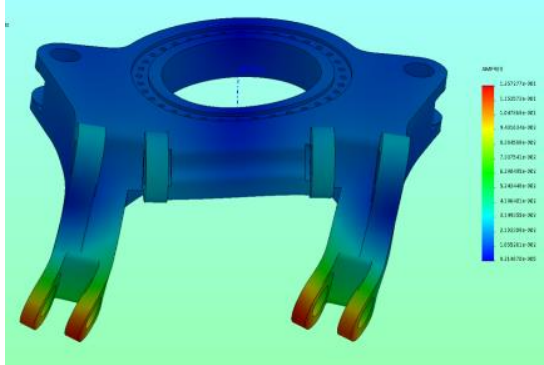

d) IV-Order

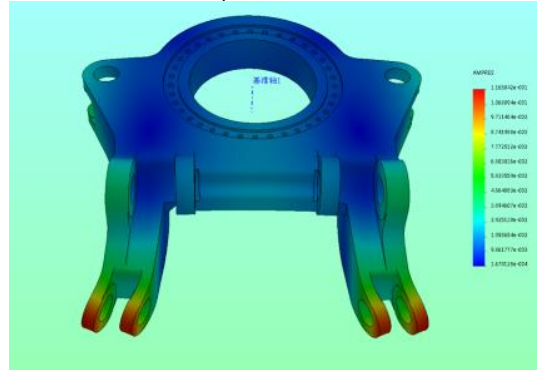

e) V-Order

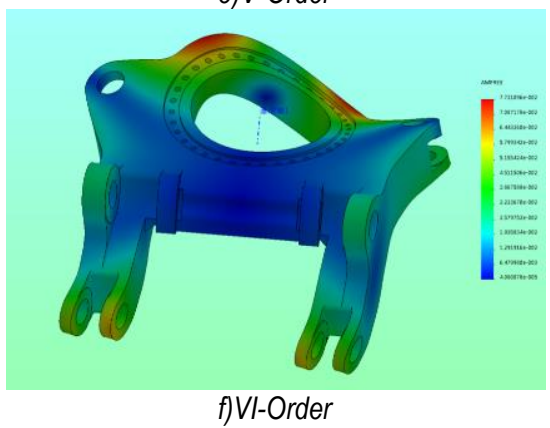

Fig.9. I-VI order vibration model of free-state rotary table 
The roadheader machine generally does not induce more intense external periodic excitation load when cutting softer coal rock roadway, and does not produce resonant damage. When cutting harder rock lanes, it will produce external periodic excitation load and the following conditions should be noted: 1. Whether the excitation frequencies of the external excitation load is the same or close to the natural frequency of a certain order; 2 . Whether the periodic change direction of the load coincides with or basically coincides with the direction of change of a certain order mode; 3. Whether the external excitation load is continuous. According to these three aspects, if these three conditions are consistent with a certain order mode, the structure of the rotary needs to be redesigned, and the static and modal analysis is carried out again according to the redesigned model to ensure that the strength and stiffness of the rotary are sufficient and that no resonance is generated during the cutting process.

\section{FATIGUE ANALYSIS OF ROTARY TABLE}

\subsection{Establishment of S-N curve of rotary table}

The EBZ160 Roadheader machine rotary table is designed for large low-alloy steel castings. It is made of $\mathrm{Zg} 35 \mathrm{CrMo}$ with $\mathrm{C}$ content of $0.3 \%$ $0.37 \%$, Si content of $0.3 \%-0.5 \%$, Mn content of $0.5 \%-0.8 \%, \mathrm{P}$ content of less than $0.035 \%, \mathrm{Cr}$ content of $0.8 \%-1.2 \%$, and Mo content of $0.2 \%-$ $0.3 \%$. Its yield limit is above $510 \mathrm{MPa}$, strength limit is $740-880 \mathrm{MPa}$, and the overall strength is relatively high.

The basic S-N curve describing the fatigue properties of the material is given by the symmetric cyclic fatigue test at $R=-1$. Approximate estimates can also be made by consulting the relevant manual based on material strength limit $\sigma_{\mathrm{b}}$ in Refs. [23, 24].

Through considerable experience and experimental accumulation, the following empirical relationship has been derived for the general use of metal materials:

The fatigue limit $\mathrm{R}=-1$ under bending load could be estimated as:

$$
\sigma_{-1}= \begin{cases}0.5 \sigma_{\mathrm{b}} & \sigma_{\mathrm{b}}<1400 \\ 700 & \sigma_{\mathrm{b}} \geq 1400\end{cases}
$$

The fatigue limit $\mathrm{R}=-1$ under axial tensile pressure load could be estimated as: $\sigma_{-1}=0.35 \sigma_{\mathrm{b}}$.
The fatigue limit $\mathrm{R}=-1$ under torsional load can be estimated as: $\sigma_{-1}=0.29 \sigma_{\mathrm{b}}$.

The S-N curve generally has a form $S^{m} \mathrm{~N}=\mathrm{C}$, where $\mathrm{m}$ and $\mathrm{C}$ are constants related to materials, loading forms, etc.

For metal materials, the number of cycles corresponding to the fatigue limit $\sigma_{-1}$ is generally $10^{7}$. As the S-N curve describes long life fatigue and is not suitable for the following $\mathrm{N}$ $<1000$, the fatigue stress of $\mathrm{N}=10^{3}$ was assumed to be $0.9 \sigma_{\mathrm{b}}$. In this study, the strength limit of ZG35CrMo is $740 \mathrm{MPa}$, that is: $\mathrm{N}_{1}=10^{3}$, $\mathrm{S}_{1}=0.9 \sigma_{\mathrm{b}}=666$.

The area where the roadheader is known to be weak in the left and right rotary cutting process is mainly the inner side of the truncated arm and the hinge ear of the rotary, as well as the hinge of the rotary table and the rotary hydraulic cylinder. These areas are mainly subjected to tensile loads.

$$
\mathrm{N}_{2}=10^{7}, \mathrm{~S}_{2}=\sigma_{-1}=0.35 \sigma_{\mathrm{b}}=259
$$

Thus,

$$
\begin{gathered}
\mathrm{m}=\log _{\frac{\mathrm{S}_{1}}{\mathrm{~S}_{2}}} \frac{\mathrm{N}_{2}}{\mathrm{~N}_{1}}=9.75 \\
\mathrm{C}=\mathrm{S}_{1}^{\mathrm{m}} \mathrm{N}_{1}=3.4227 \times 10^{30}
\end{gathered}
$$

The final S-N curve relation is:

$$
S= \begin{cases}\left(\frac{\mathrm{C}}{\mathrm{N}}\right)^{\frac{1}{\mathrm{~m}}} & \mathrm{~N}<10^{7} \\ \sigma_{-1} & \mathrm{~N} \geq 10^{7}\end{cases}
$$

The fatigue analysis of the EBZ160 rotary table was performed using the AWE fatigue module. The Poisson ratio was 0.3 , yield limit was 510 $\mathrm{MPa}$, strength limit was $740 \mathrm{MPa}$, and the elastic modulus $\mathrm{E}$ was $2.1 \times 1011 \mathrm{~Pa}$. A set of data was calculated by the final S-N curve relational formula in Table 1.

Table 1. A set of data was calculated by the final S-N curve

\begin{tabular}{c|c|c}
\hline $\begin{array}{c}\text { Serial } \\
\text { number }\end{array}$ & $\begin{array}{c}\text { Cycle } \\
\left.\times 10^{3}\right)\end{array}$ & $\begin{array}{c}\text { Alternating stress value } \\
(\mathrm{MPa})\end{array}$ \\
\hline 1 & 1000 & 666 \\
\hline 2 & 2000 & 620.3053 \\
\hline 3 & 4000 & 577.7458 \\
\hline 4 & 8000 & 538.1063 \\
\hline 5 & 16000 & 501.1866 \\
\hline 6 & 32000 & 466.7998 \\
\hline 7 & 64000 & 434.7724 \\
\hline 8 & 128000 & 404.9424 \\
\hline
\end{tabular}




\begin{tabular}{c|c|c}
\hline 9 & 256000 & 377.1591 \\
\hline 10 & 512000 & 351.282 \\
\hline 11 & 1024000 & 327.1803 \\
\hline 12 & 2048000 & 304.7323 \\
\hline 13 & 4096000 & 283.8244 \\
\hline 14 & 8192000 & 264.3511 \\
\hline 15 & 16384000 & 259 \\
\hline
\end{tabular}

After importing this set of data into AWE, the software automatically generated curve 10 , as shown in the following figure:

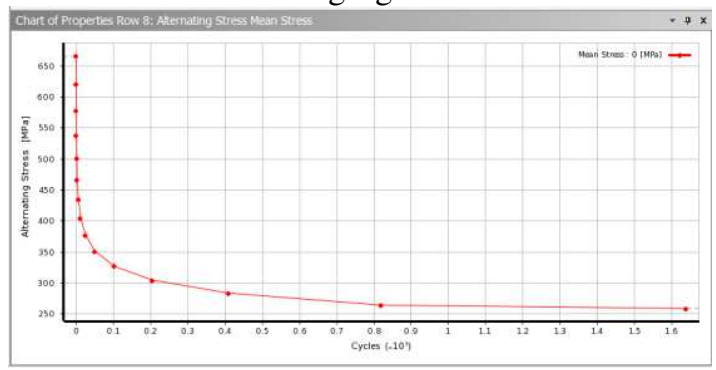

Fig.10. S-N curve derived from the calculation data

In the generated linear form and single logarithmic form $\mathrm{S}-\mathrm{N}$ curve, the whole curve is not smooth with $\mathrm{N}=108$. From the AWE module, a one-dimensional interpolation of various stress states in the form of a set of input data was performed, and the S-N curve of the linear form of ZG35CrMo was obtained, as shown in Figure 11. The $\mathrm{S}-\mathrm{N}$ curve of the single logarithmic form of ZG35CrMo obtained by interpolation is shown in Figure 12.

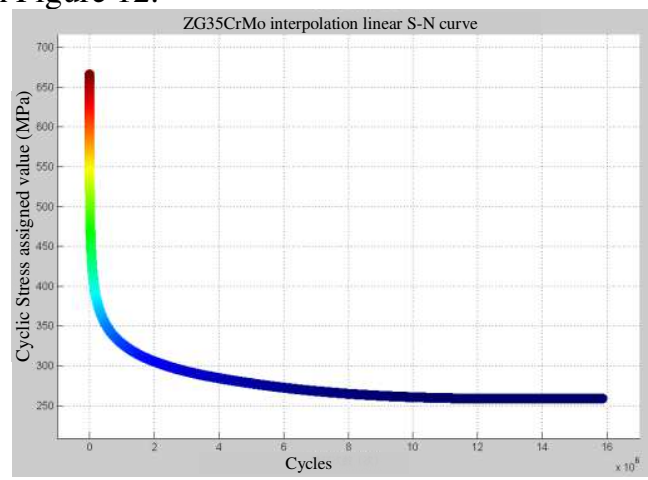

Fig.11. One dimensional interpolation of the $S-N$ curve of the linear form of ZG35CrMo

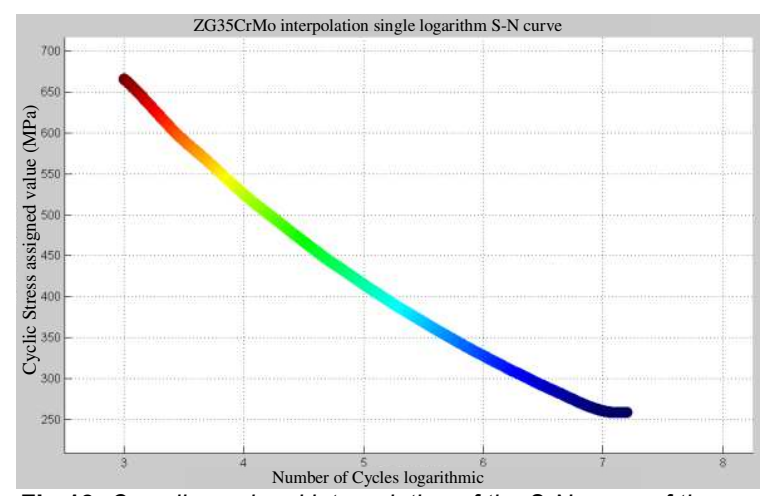

Fig.12. One-dimensional interpolation of the S-N curve of the single logarithmic form of ZG35CrMo

\subsection{Fatigue analysis}

According to the previous static analysis results, the loading mode of the maximum stress was selected to load the rotary. The stress cloud diagram of the rotary is shown in Figure 13, with a maximum stress of $502.96 \mathrm{MPa}$, which is located inside the hinged ear of the rotary and the cutting part.

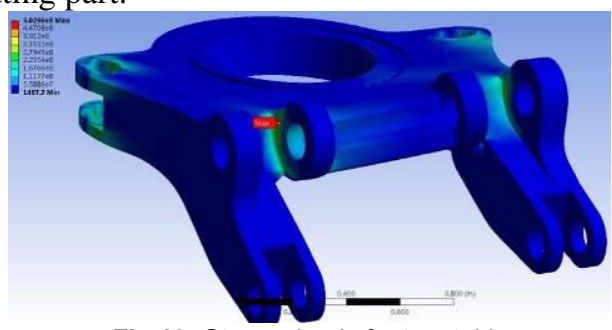

Fig.13. Stress cloud of rotary table

The results of fatigue analysis of the rotary using AWE show that the number of cycles in the most critical areas is 15,615 times, as shown in Figure 14.

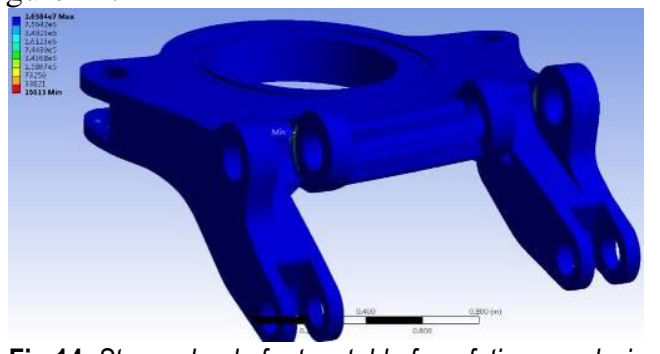

Fig.14. Stress cloud of rotary table from fatigue analysis using AWE

In the process of cutting and digging of the EBZ160 roadheader machine, the cutting part cuts a section according to the class $\mathrm{S}$ type from bottom to top at a rate of about $1 \mathrm{~m}$ at a time. When the coal rock of the roadway is hard, the EBZ160 roadheader machine cuts in the maximum output state, and fatigue crack appears 
in the inner side of the hinged ear when the excavation reaches $7807 \mathrm{~m}$.

At $75 \%$ of the maximum output state, the maximum stress of the rotary was $377.22 \mathrm{MPa}$, which was identified inside of the hinge ear of the rotary and the cutting part. Using AWE to analyze the fatigue of the rotary table, the number of cycles at the most critical areas was $2.557 \times 105$ times. When the cutting operation was performed with a maximum output state of $75 \%$, the excavation operation of the roadheader machine could reach $127900 \mathrm{~m}$ before the appearance of fatigue crack on the inner side of the hinged ear.

At $50 \%$ of the maximum output state, the maximum stress of the rotary was $251.48 \mathrm{MPa}$, which was identified on the inside of the hinged ear of the rotary table and the cutting part. In the AWE fatigue analysis, the number of cycles at the most critical areas was $1.6384 \times 107$ times. No fatigue failure is expected in the rotary table of the roadheader machine when the cutting operation is carried out with a maximum output state of $50 \%$.

From the data of the EBZ160 roadheader, the cutting output load is generally about $50 \%$ of the maximum output load. Therefore, fatigue damage is not likely to occur in the rotary table. Although the maximum output load may be reached occasionally, it will not cause fatigue damage because this situation lasts only for a short time. Even assuming that the roadheader machine is operated with a maximum output load of $75 \%$, the above analysis shows that the roadheader can still continue excavating up to $127900 \mathrm{~m}$ before the appearance of fatigue cracks. According to the current known EBZ160 roadheader machine, with a maximum monthly excavation of $1000 \mathrm{~m}$, it can last for more than 10.66 years before the appearance of fatigue damage. This greatly exceeds the normal length of service of the roadheader machine.

Therefore, the rotary table does not face the risk of fatigue damage with the roadheader machine under normal working loads and normal service life.

\section{VIBRATION ANALYSES OF ROTARY TABLE} BASED ON WELL UNIDO CONDITION

In order to further verify the reliability of the rotary table, vibration analysis of the rotary table was carried out by measuring the UNIDO conditions of the well. According to the structure characteristics of the roadheader machine and the actual working conditions of the fully mechanized excavation face in the coal mine, key parts such as cutting arm, rotary table and main frame were selected. Each measuring point was measured from the horizontal and vertical directions, and the vibration data were collected. The distribution of measuring points is shown in Figure 15, and the corresponding relationship of the measuring point is shown in Table 2. The rotary table and cutting arm were set as key test sites because vibration and damage of the roadheader machine mainly occurs in these parts.

There are four main types of movement of the cutting head of the longitudinal roadheader machine: rotation of the cutting head along the direction of the cutting motor; cutting by the roadheader machine along the forward axis of the roadway; rotation of the cutting head horizontally along the roadway under the drive of the cutting arm; and longitudinal cutting [25]. In order to understand the vibration frequency domain characteristics of each key part of the roadheader, taking the vibration data of each measuring point in the normal cutting roadway as an example, the vibration spectrum structure characteristics of different measuring points of the roadheader machine were analyzed in the form of frequency domain power spectrum.

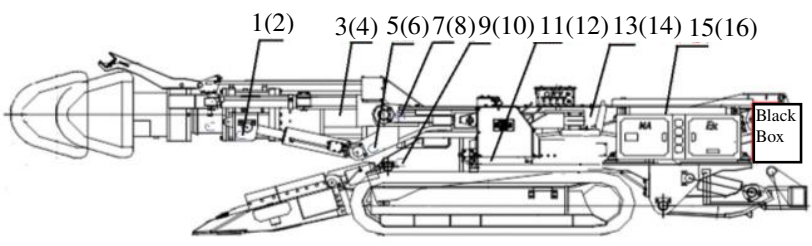

Fig.15 Schematic of the arrangement of measuring points in the roadheader

Table 2. Corresponding relationship of the measured points

\begin{tabular}{|c|c|c|}
\hline Number & Location of the measuring point & Sensors \\
\hline 1 & $\begin{array}{l}\text { Connection between the cutting } \\
\text { arm and the lifting cylinder } \\
\text { (horizontal) }\end{array}$ & 1 \\
\hline 2 & $\begin{array}{l}\text { Connection between the cutting } \\
\text { arm and the lifting cylinder } \\
\text { (vertical) }\end{array}$ & 2 \\
\hline 3 & Rear of the cut arm (horizontal) & 3 \\
\hline 4 & Rear of the cut arm (vertical) & 4 \\
\hline 5 & $\begin{array}{l}\text { Junction of the rotary table and the } \\
\text { lifting cylinder (horizontal) }\end{array}$ & 5 \\
\hline
\end{tabular}




\begin{tabular}{|c|c|c|}
\hline 6 & $\begin{array}{c}\text { Junction of rotary table and lifting } \\
\text { cylinder (vertical) }\end{array}$ & 6 \\
\hline 7 & $\begin{array}{c}\text { Top part of rotary table } \\
\text { (horizontal) }\end{array}$ & 7 \\
\hline 8 & $\begin{array}{c}\text { Top part of rotary table } \\
\text { (vertical) }\end{array}$ & 8 \\
\hline 9 & $\begin{array}{c}\text { Bottom part of rotary table } \\
\text { (horizontal) }\end{array}$ & 9 \\
\hline 10 & $\begin{array}{c}\text { Bottom part of rotary table } \\
\text { (vertical) }\end{array}$ & 10 \\
\hline 11 & Mainframe Rack (vertical) & 11 \\
\hline 12 & Mainframe Rack (horizontal) & 12 \\
\hline 13 & $\begin{array}{c}\text { Rear part of rotary table } \\
\text { (horizontal) }\end{array}$ & 13 \\
\hline 14 & $\begin{array}{c}\text { Rear part of rotary table } \\
\text { (vertical) }\end{array}$ & 14 \\
\hline 15 & $\begin{array}{l}\text { Horizontal measuring point of } \\
\text { electronic control box }\end{array}$ & 15 \\
\hline 16 & $\begin{array}{l}\text { Vertical measuring point of } \\
\text { electronic control box }\end{array}$ & 16 \\
\hline
\end{tabular}

In the vibrator, a vibration acceleration sensor and a cable with Mine Safety certificate as the sensing line were adopted. The sensor could measure multiple directional signals at the same point simultaneously using a multidirectional magnetic suction seat, which is very practical. The sensor and the vibration meter coupling is shown in Figure 16.

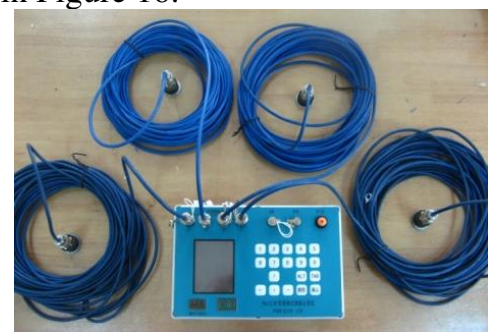

Fig.16 Photograph of the sensor and the vibration meter coupling

The signal power spectrum was obtained using Fast Fourier Transform (FFT), and frequency domain analysis of the collected vibration signal was performed. The vibration characteristic frequency of the drive system of the roadheader machine is mainly attributable to the meshing frequency of the transmission deceleration gear at all levels of the cutting part. For the EBZ160 roadheader machine cutting part, a rated speed of 1483/733 r/min was used for a $160 / 100 \mathrm{~kW}$ motor. Generally, in high-speed cutting, the cutting head is in the rotating motor after the deceleration of the two-stage planetary gear reducer through the output shaft transmission, with a transmission ratio of 31.03 . According to the transmission gear parameters of the transmission system at all levels, the speed of each gear shaft, the frequency of rotation, and the meshing frequency of each adjacent gear can be calculated.

The spectrum diagram (that is, the power spectrum) for the whole cutting process of the rotary table of the roadheader was analyzed emphatically, as shown in Figures 17 and 18.

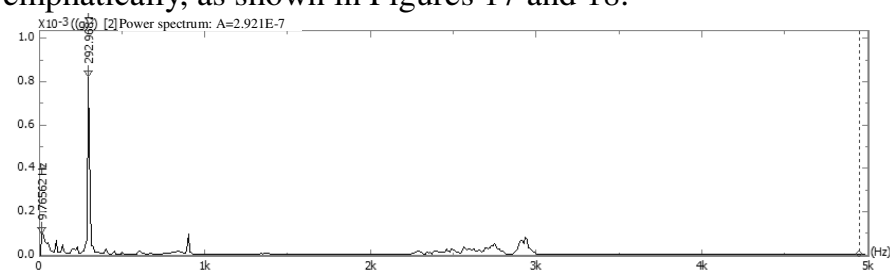

Fig.17 Vibration frequency spectrum of the upper part of

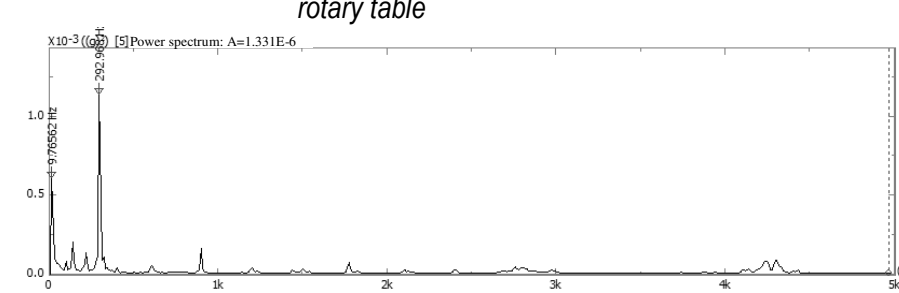

Fig.18 Vibration frequency spectrum of the lower part of rotary table

The dominant frequency is $292.969 \mathrm{~Hz}$, and this frequency is the meshing frequency of the truncated gearbox. The more advantageous frequencies of each measuring point are concentrated below $500 \mathrm{~Hz}$, which is a typical low-frequency vibration.

The vertical measuring point of the rotary table was set for spectrum analysis, and the frequency and amplitude of the characteristics were statistically analyzed (see Figure 19 and Table 3 for details).

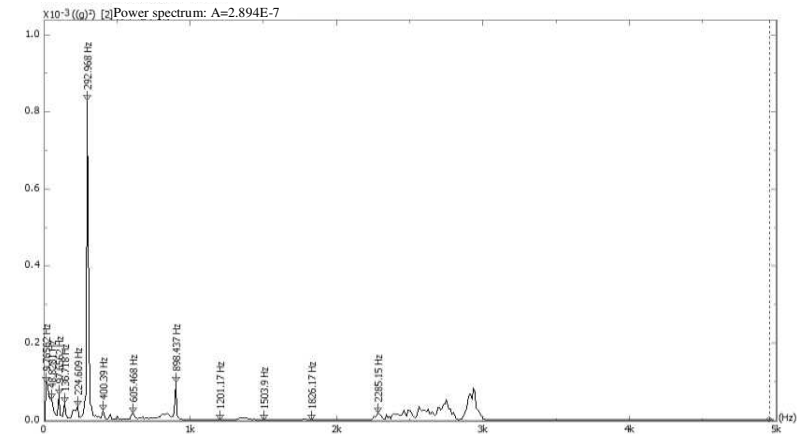

Fig.19 Frequency diagram of rotary table vibration 
Table 3. Main characteristic frequency statistics of the rotary table

\begin{tabular}{|c|c|c|c|c|}
\hline \multirow{2}{*}{$\begin{array}{c}\text { Frequenc } \\
y \\
\text { multiplic } \\
\text { ation } \\
\text { times }\end{array}$} & \multicolumn{2}{|r|}{ Level } & \multicolumn{2}{|c|}{ Leve2 } \\
\hline & $\begin{array}{c}\text { Feature } \\
\text { frequency } \\
(\mathrm{Hz})\end{array}$ & $\begin{array}{l}\text { Amplitude } \\
\text { value } \\
\left(\mathrm{g}^{2}\right)\end{array}$ & $\begin{array}{c}\text { Feature } \\
\text { frequency } \\
(\mathrm{Hz})\end{array}$ & $\begin{array}{l}\text { Amplitude } \\
\text { value } \\
\left(\mathrm{g}^{2}\right)\end{array}$ \\
\hline 1 & 292.969 & $8.310 \mathrm{E}-4$ & 48.8281 & $5.492 \mathrm{E}-5$ \\
\hline 2 & 605.469 & $1.977 \mathrm{E}-5$ & 97.6563 & $6.839 \mathrm{E}-5$ \\
\hline 3 & 898.438 & $9.878 \mathrm{E}-5$ & 136.719 & $4.631 \mathrm{E}-5$ \\
\hline 4 & 1201.17 & $1.895 \mathrm{E}-6$ & 195.313 & $2.662 \mathrm{E}-5$ \\
\hline 5 & 1435.55 & $2.288 \mathrm{E}-6$ & 224.609 & $3.661 \mathrm{E}-5$ \\
\hline 6 & 1777.34 & $4.543 \mathrm{E}-6$ & I & I \\
\hline
\end{tabular}

The main spectrum structure of the vibration of the rotary table can be obtained from Table 3, which includes the base frequency of the rotation meshing frequency of the first-stage deceleration gear group and its high sub-frequency (2-6 frequency multiplication) at all levels, and the base frequency of the rotation meshing frequency of the secondary deceleration gear group and its partial high frequency multiplication (2-5 multiplication). It also includes the vibration frequency and other frequencies of the cutting head when cutting the coal.

The above analysis has important guiding significance for the optimization of rotary table structure.

Overall, the performance of the fully designed rotary table is reliable, and it can satisfy the requirements of field operation; under normal working load and normal service life, fatigue damage will not occur.

\section{CONCLUSION}

As the key part of the roadheader machine, the performance of the rotary table has a great influence on the efficiency and dynamic reliability of the roadheader machine. The main results of the study are as follows:

(1) The load stress and strain of the rotary table of the tunneling machine were studied. The structure of the rotary table of the roadheader machine was analyzed, and the virtual prototype dynamics simulation model of the cutting part and the rotary table was established using the automatic dynamic analysis of the mechanical systems simulation environment. Force analysis was carried out and the static finite element analysis of the rotary table was performed by selecting three groups at the left and right ends of the bottom, middle, and upper segments of the cutting head. The results show that the stress of the rotary table is close to the yield limit when the maximum output is calculated. Furthermore, the maximum dynamic characteristics of the whole machine were found to be in good agreement with the strength of the rotary table structure. Accordingly, the rotary table is not prone to fatigue damage.

(2) The modal analysis of the turntable was performed with the rotary table in the free state. The 6-order modal mode of the rotary table was obtained, and three considerations are put forward. If these three conditions coincide with a certain order mode, the structure of the rotary table needs to be redesigned, and the static and modal analyses were performed again according to the redesigned model to ensure that the strength and stiffness of the rotary table are sufficient and that no resonance is generated during the cutting process.

(3) The fatigue analysis of the turntable was performed. The S-N curve of the rotary table was established, and the fatigue life reliability of the rotary table was analyzed using AWE. The results show that the maximum stress of the rotary table occur inside the hinged ear of the rotary table and the cutting part.

Based on the above research, if favorable working conditions are maintained, the EBZ160 type roadheader machine will not experience fatigue damage under normal working load and normal service life of the rotary table.

\section{ACKNOWLEDGMENTS}

This work are supported by the National Basic Research Pro-gram (973 Program; No. 2014CB046306) under the Ministry of Science and Technology, China; the Yue Qi Young Scholar Project under the China University of Mining and Technology, China.

\section{REFERENCES}

[1] C. Y. Wang. (2010). Optimal Design about Turning Platform of EBZ-135 Cantilever Type Roadheader[D]. Taiyuan University of Technology.

[2] O. Acaroglu and C. Erdogan. (2017). Stability analysis of roadheaders with mini-disc [J]. Tunnelling and Underground Space Technology, 68 (9) 187-195.

[3] M. Dolipski, P. Cheluszka, and P. Sobota. (2015). Investigating the simulated control of the 
rotational speed of roadheader cutting heads, relating to the reduction of energy consumption during the cutting process[J]. Journal of Mining Science, 51 (2) 298-308.

[4] S. Faradonbeh et al., (2017). Roadheader performance prediction using genetic programming (GP) and gene expression programming (GEP) techniques [J]. Environmental Earth Sciences, 76 (16) 1-12.

[5] A. Salsani et al., (2014). Predicting roadheader performance by using artificial neural network [J]. Neural Computing and Applications, 24 (7-8) 1823-1831.

[6] E. Avunduk, D. Tumac, and A. K. Atalay. (2014) .Prediction of roadheader performance by artificial neural network [J]. Tunnelling and Underground Space Technology, 443-9.

[7] P. Cheluszka et al., (2018). Modelling the dynamics of a drive of boom-type roadheader cutting heads at adjustable angular speed [J]. Archives of mining sciences, 63 (1) 183-24.

[8] J. S. Jang et al., (2016).Cutting Head Attachment Design for Improving the Performance by using Multibody Dynamic Analysis [J]. International journal of precision engineering and manufacturing, 17 (3) 371-377.

[9] L. J. Zhao, M. H. Li, and P. H. Zhang. (2017). Dynamic reliability and fatigue life analysis of the roadheader's gyration platform [J]. Journal of Mechanical Strength. 39 (4) 887-892.

[10] X. N. Liu. (2014). Roadheader's Dynamic Reliability and Its Key Technologies Research [D]. Liaoning technical university.

[11] X. H. Wei.(2012).Dynamic Characteristic Analysis and Performance Prediction of Cutting Process for boom-type Roadheader [D]. Liaoning technical university.

[12] L. J. Zhao, J.Y. Wang, and X. Zhu.(2018). Cutting performance evaluation of a roadheader machine by PCA and RBF. Simulation-transactions of the society for modeling and simulation international [J]. SIMULATION-TRANSACTIONS OF THE SOCIETY FOR MODELING AND SIMULATION INTERNATIONAL 94 (12) 1129-1141.

[13] D. Liu.(2018). Study on Optimal Design of Rotary Mechanism of EBZ-300 Longitudinal Roadheader[D]. Dalian University of Technology.

[14] Q. L. Chen. (2012).Research on the Dynamical Characteristics of Rotating Part of EBH360 Type Horizontal Axis Road-header [D]. Dalian University of Technology.
[15] M. Zhang et al., (2010). Analysis of Dynamic Characteristics of Rotary Mechanism for Boom Type Roadheader[J]. Applied Mechanics and Materials, 37-38,122-126.

[16] Ch. H. Gao, and R. P. Xiao.(2017). Finite Element Analysis on Turret of EBH350 Roadheader Based on [J]. Coal Mine Machinery, 38 (8) 183-185.

[17] M. J. Zhang et al., (2018). Analysis of vibration of roadheader rotary table based on finite element method and data from underground coalmine[J]. Shock and Vibration. (47) 777-780.

[18] J. L. Zhou. (2011). Research on vibration characteristics of heavy roadheader cutting unit [D]. Liaoning technical university.

[19] Q. B. Rong. (2013). Design and experimental study on rotary table of roadheader[D]. Harbin Institute of Technology.

[20] Y. Yang, G. W. Li, and A. H. Yuan. (2017). Performance Analysis of a Hybrid Power Cutting System for Roadheader[J] Mathematical Problems in Engineering, 1-12

[21] L. SH. Zhang. (2017). Research on the measurement and analysis method of roadheader load spectrum based on data recorder [D]. China University of Mining and Technology (Beijing), Beijing.

[22] J. Tian, S. Y. Wang, and M. Wu. (2018). Kinematic models and simulations for trajectory planning in the cutting of Spatially-Arbitrary crosssections by a robotic roadheader[J]. Tunnelling and Underground Space Technology, 78 115-123.

[23] CH. D. Wang.(2012). Study on wheelset reliability of high speed emu [D]. Southwest Jiaotong University.

[24] B. L. Yang. (2013). Structure Analysis of A Certain Type of Subway Vehicle Bogie Frame under Virtual Test Bench [D]. Chong qing Jiao tong University.

[25] Y.L.HU.(2015) .Study on Roadheader's Vibration Characteristics Based on Working Conditions in Coal Mine[D]. China University of Mining and Technology (Beijing), Beijing. 


\section{Figures}

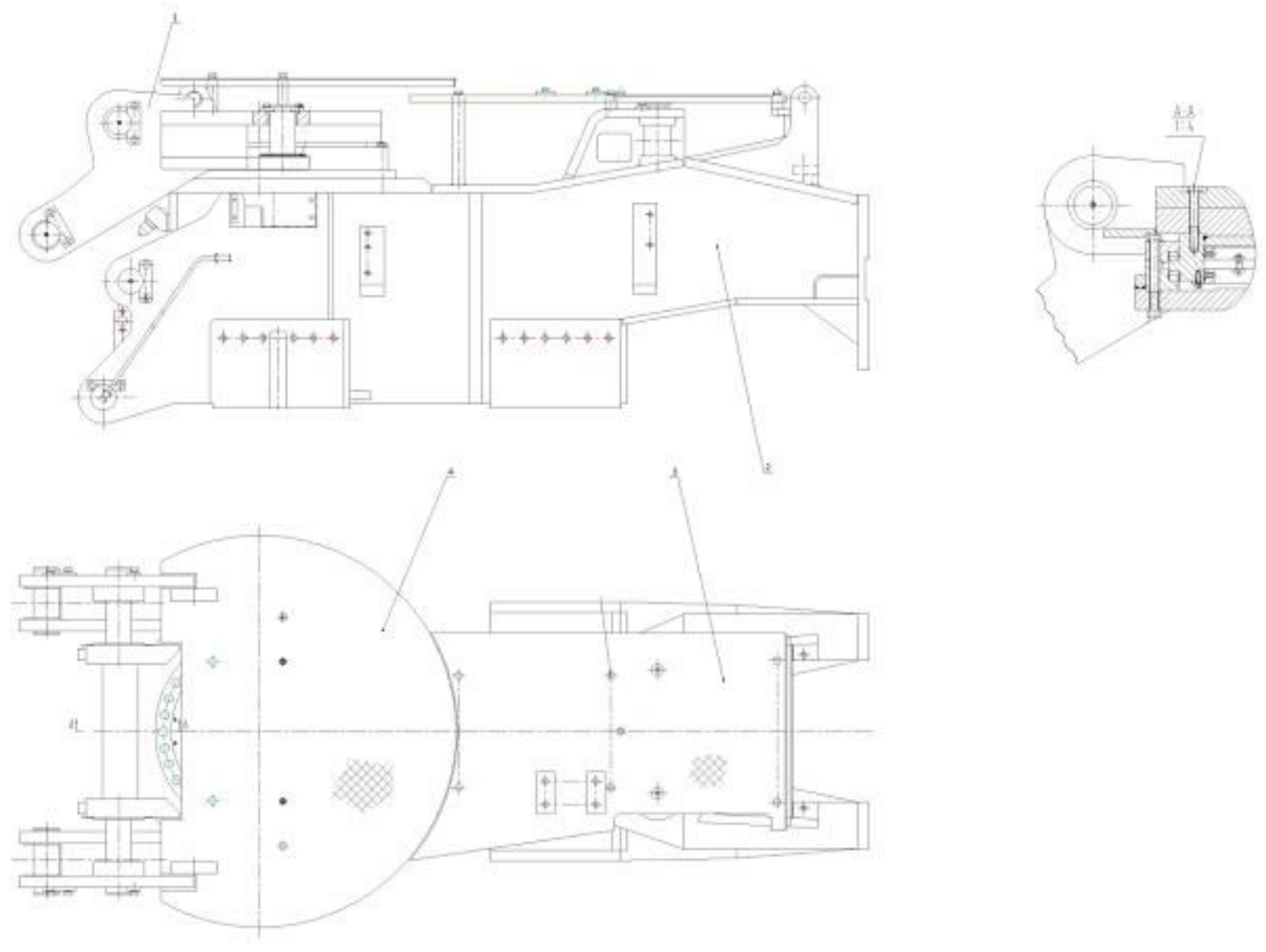

Figure 1

Body part (main frame) 1. Rotary table, 2.Body part, 3. Upper cover plate, 4. Lower cover plate

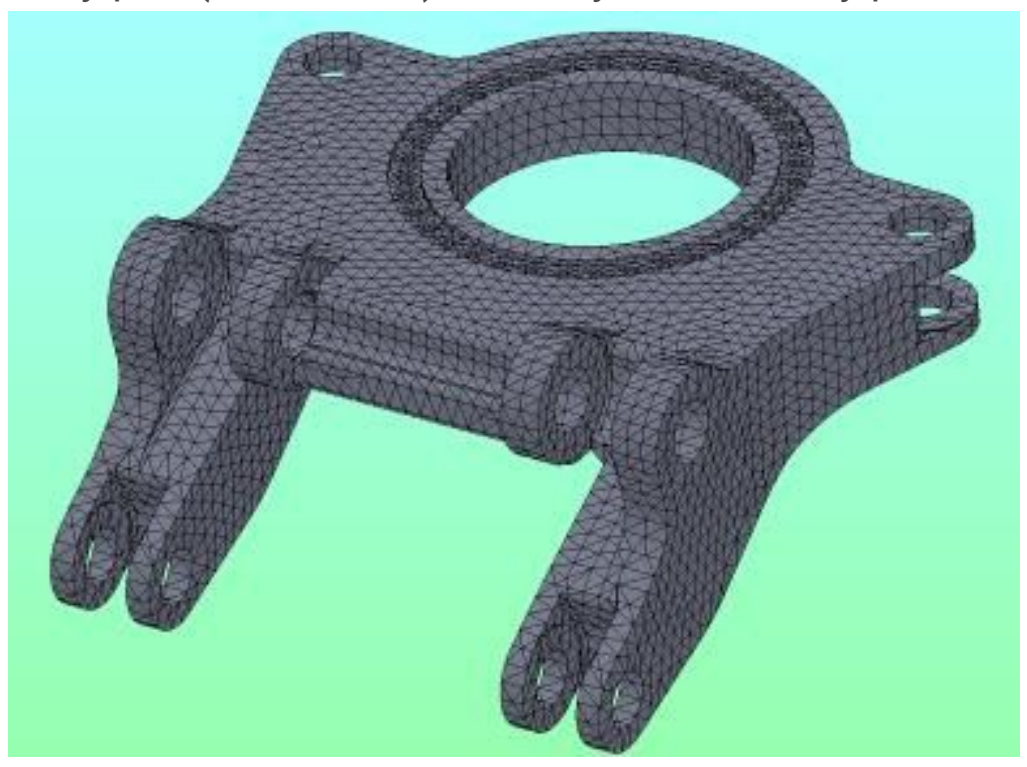

Figure 2 
Mesh of the rotary table

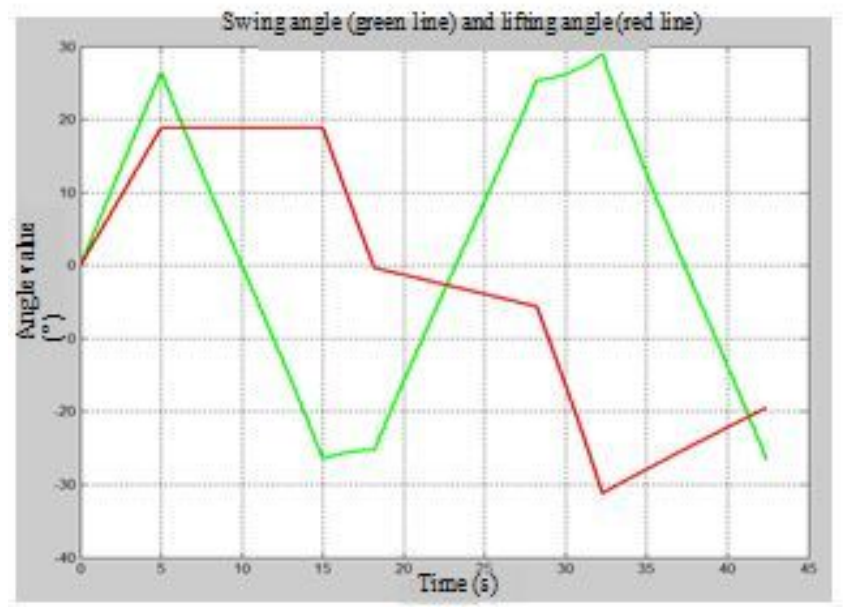

Figure 3

Swing angle and lifting angle curve for a roadheader cut by path

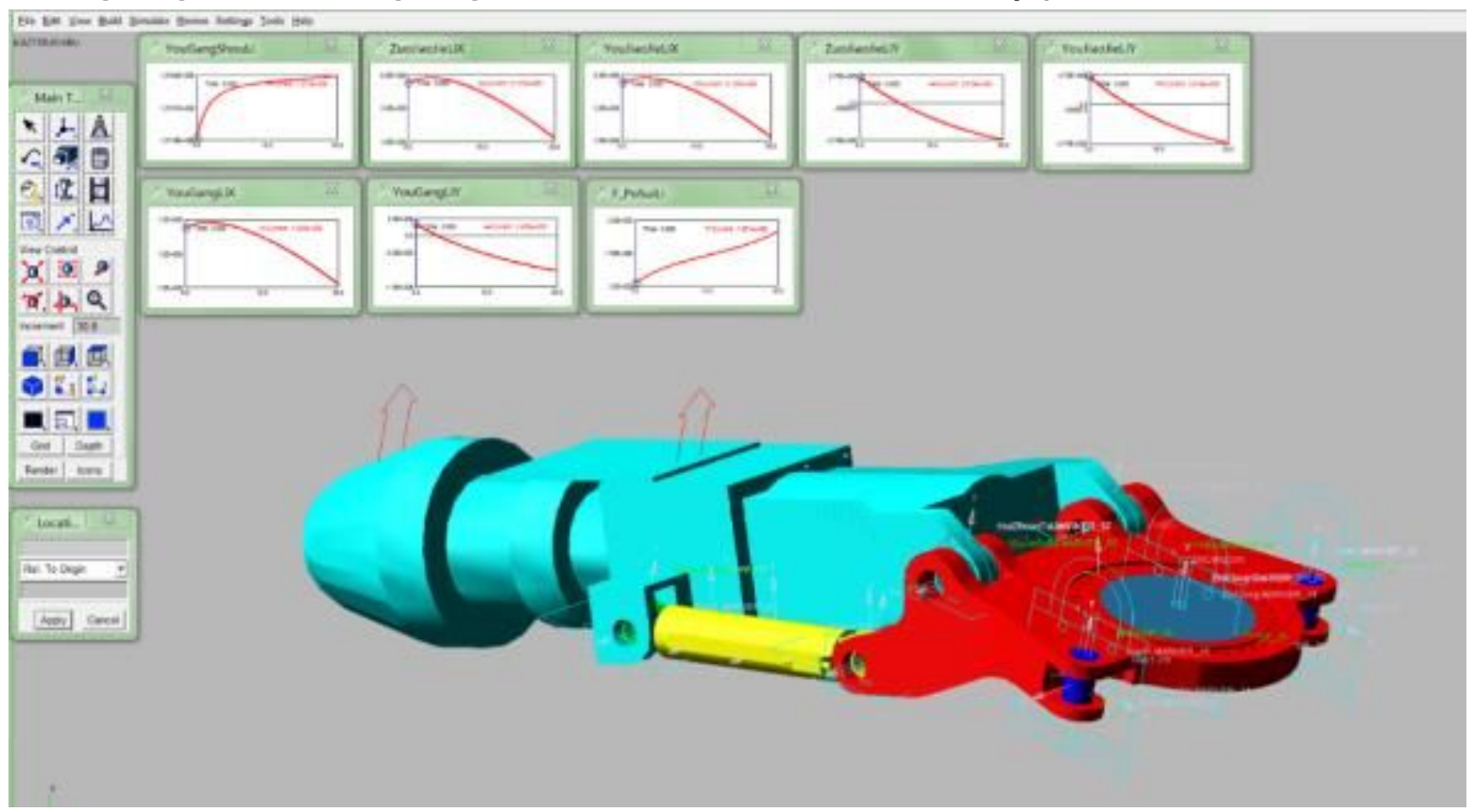

Figure 4

Virtual simulation model for cutting part and rotary table during the lifting and cutting process 


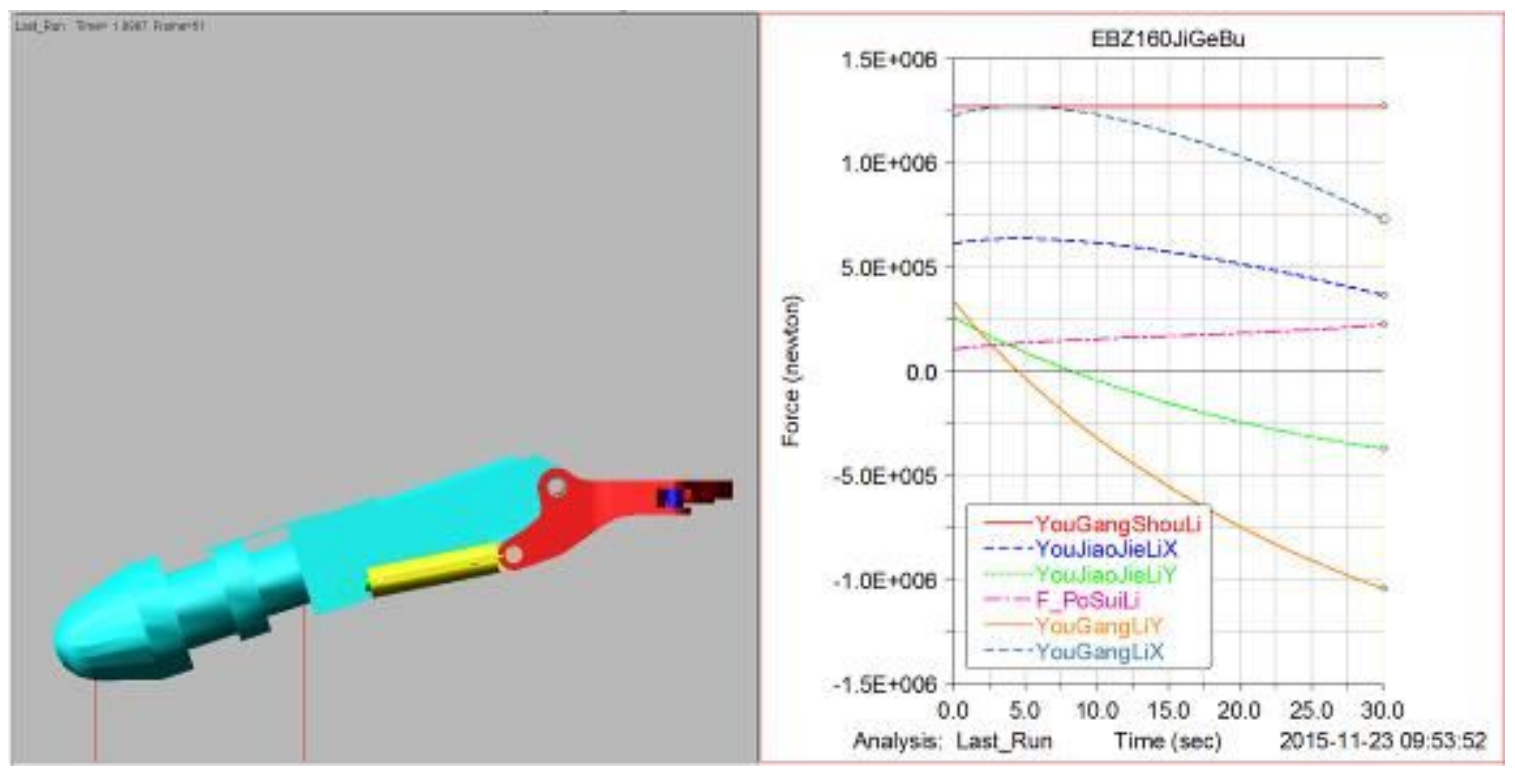

Figure 5

Stress state of each hinge joint when the cutting head cuts from bottom to top 


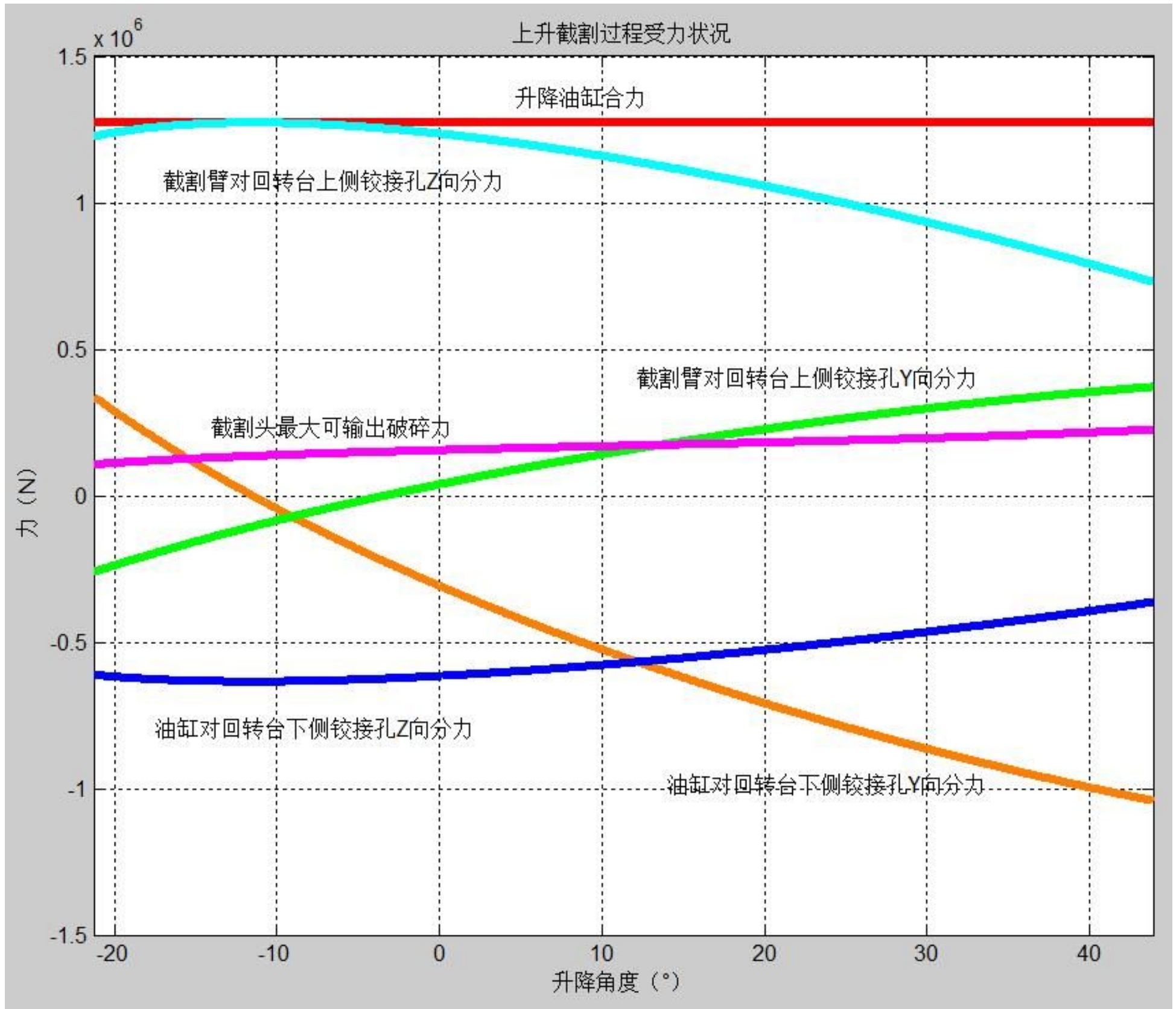

Figure 6

Stress state of each hinge joint during lifting and cutting after adjustment 


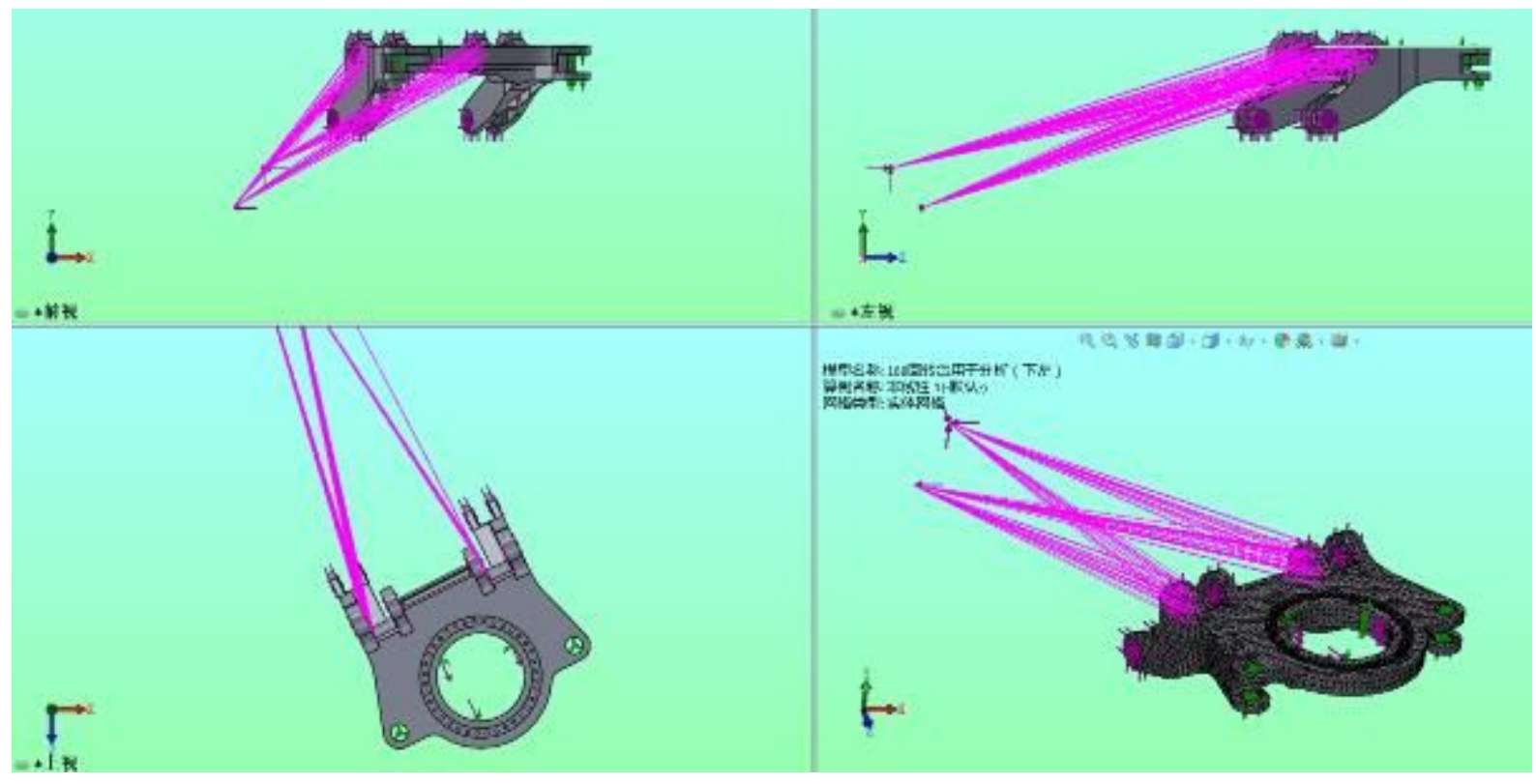

\section{Figure 7}

Finite element analysis model for the cutting head in the left end of the lower section

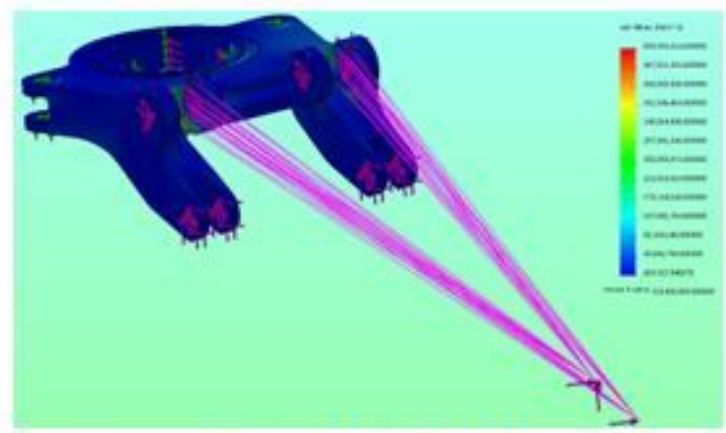

a) Stress Cloud Diagram

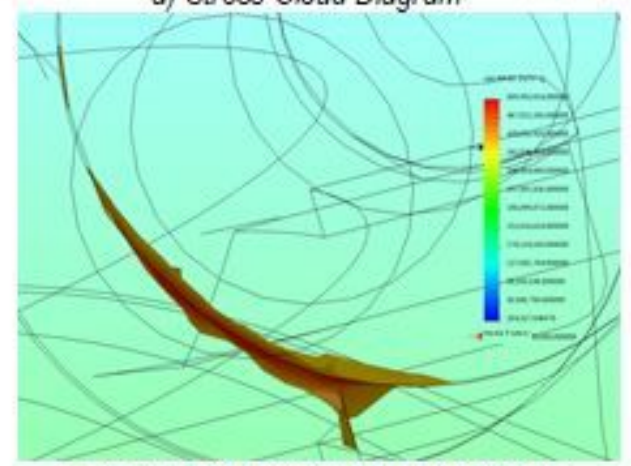

b) Stress value exceeds area cloud map

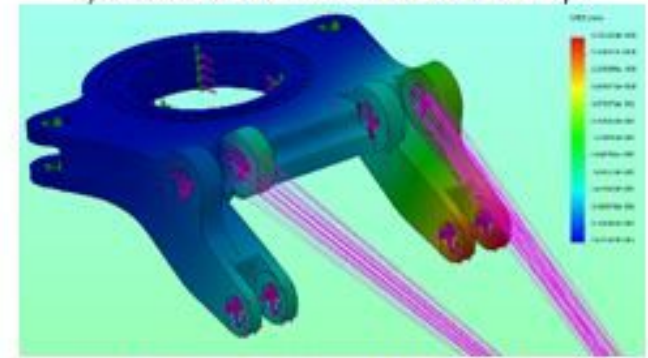

c) Combined Displacement Cloud Map

Figure 8 
Stress cloud for the cutting head in the left end of the lower section

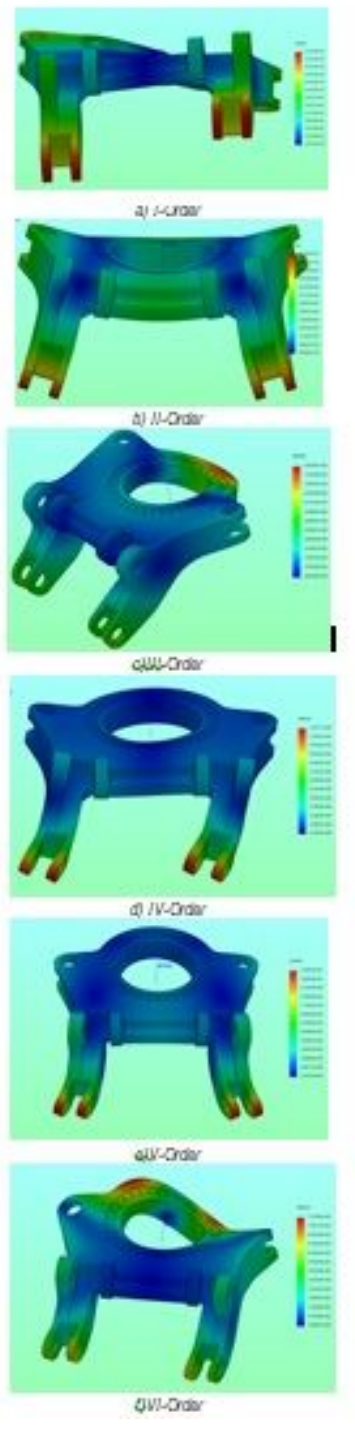

Figure 9

I-VI order vibration model of free-state rotary table 


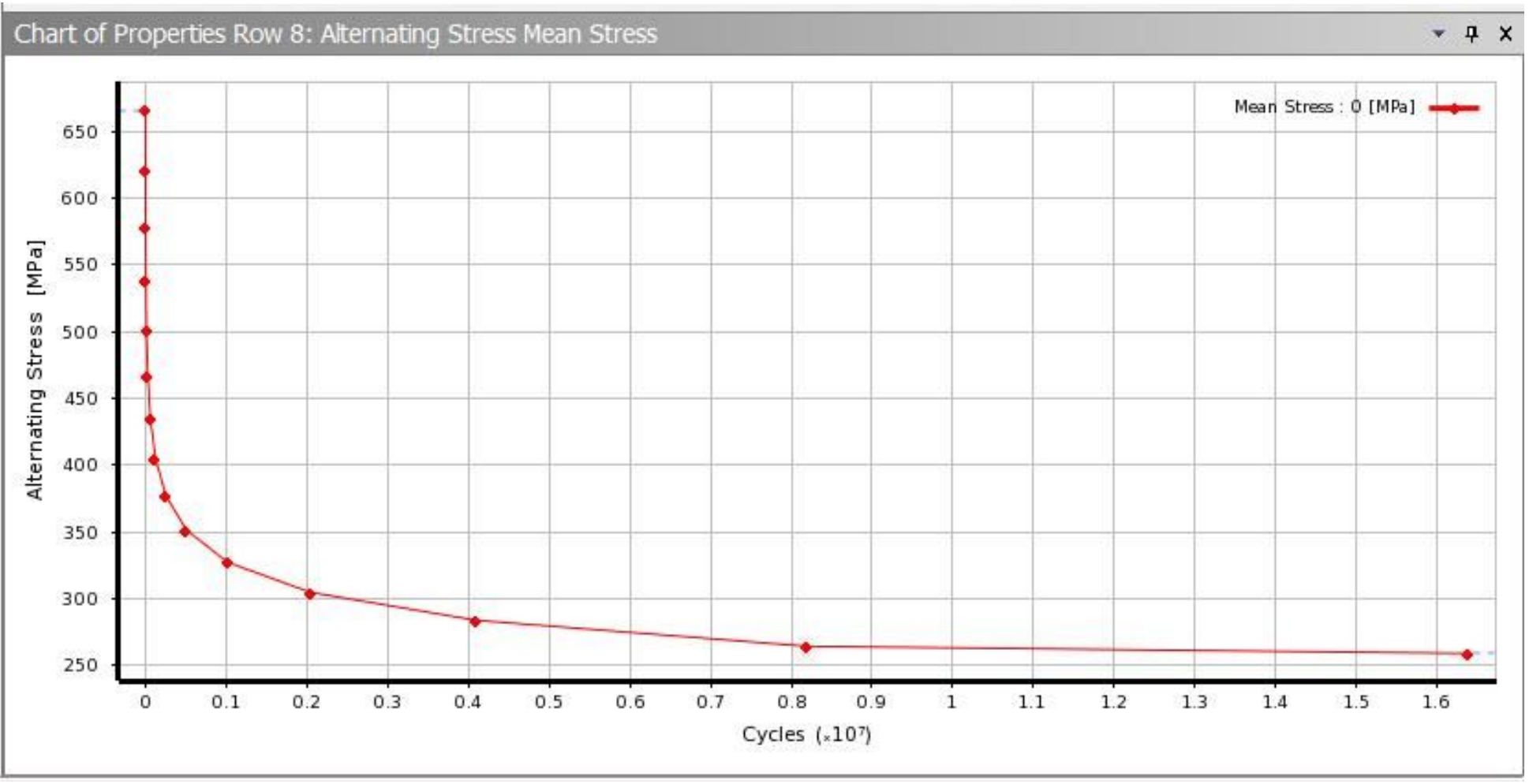

Figure 10

S-N curve derived from the calculation data 


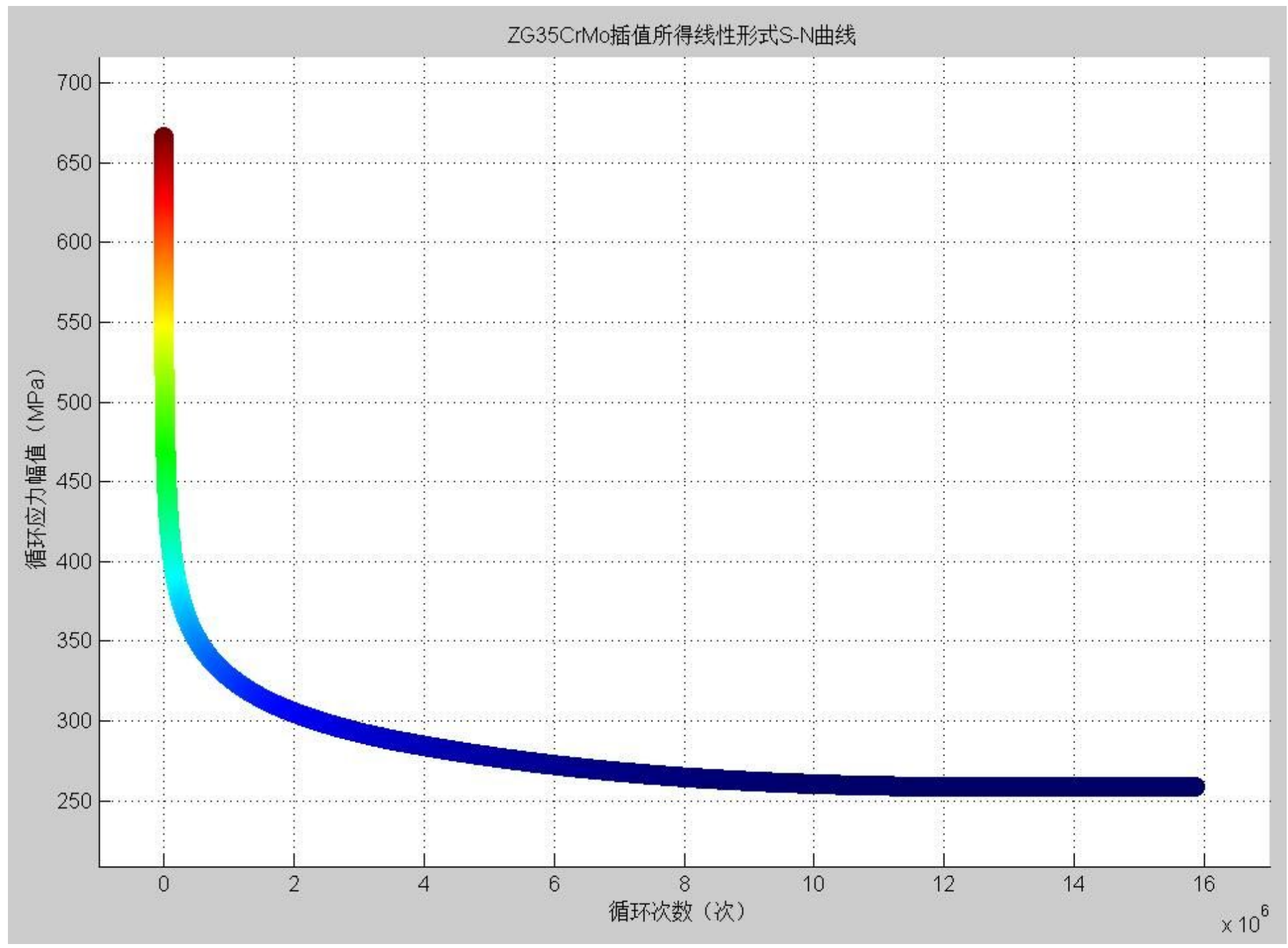

Figure 11

One dimensional interpolation of the S-N curve of the linear form of ZG35CrMo 


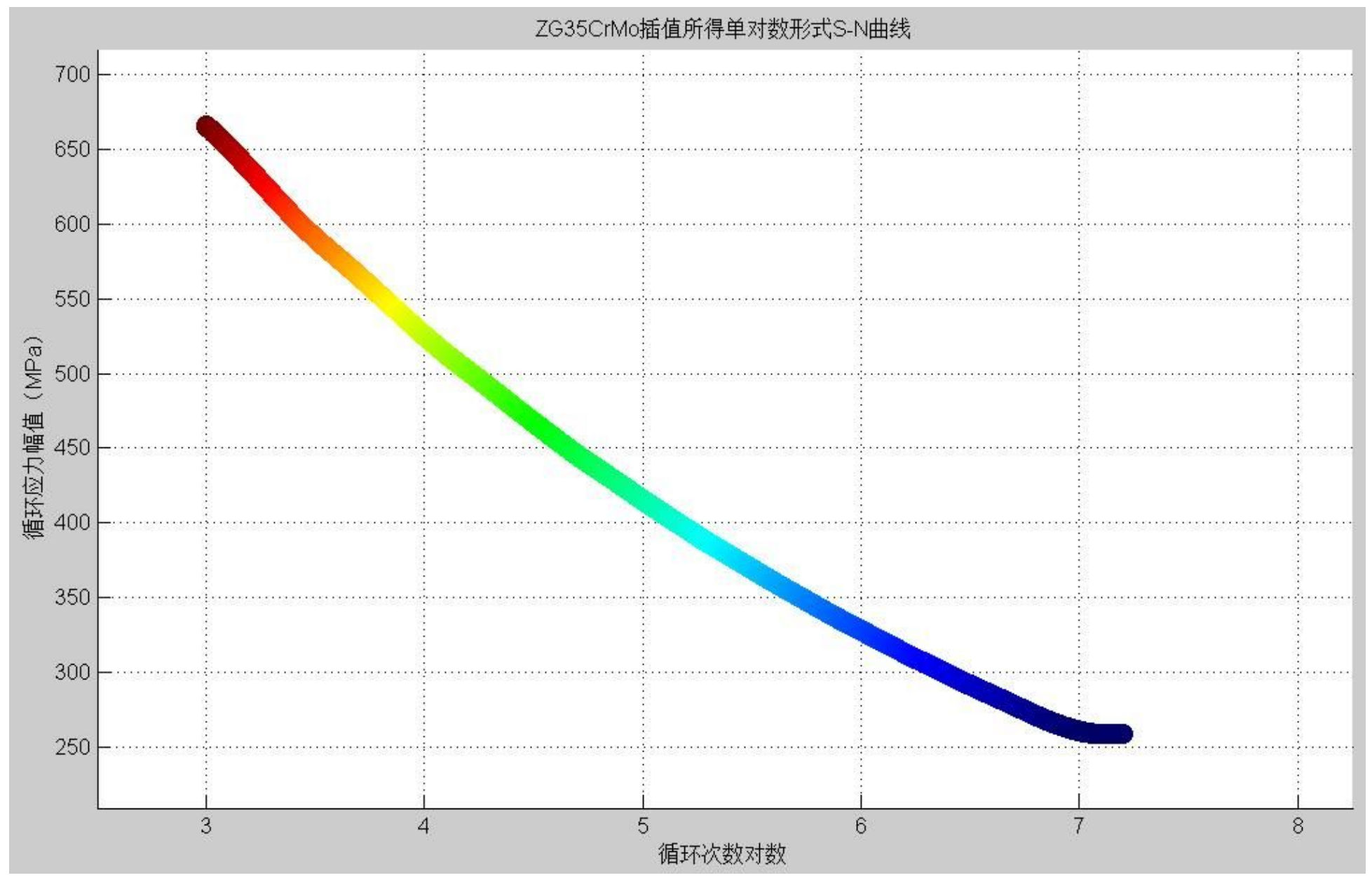

Figure 12

One-dimensional interpolation of the S-N curve of the single logarithmic form of ZG35CrMo

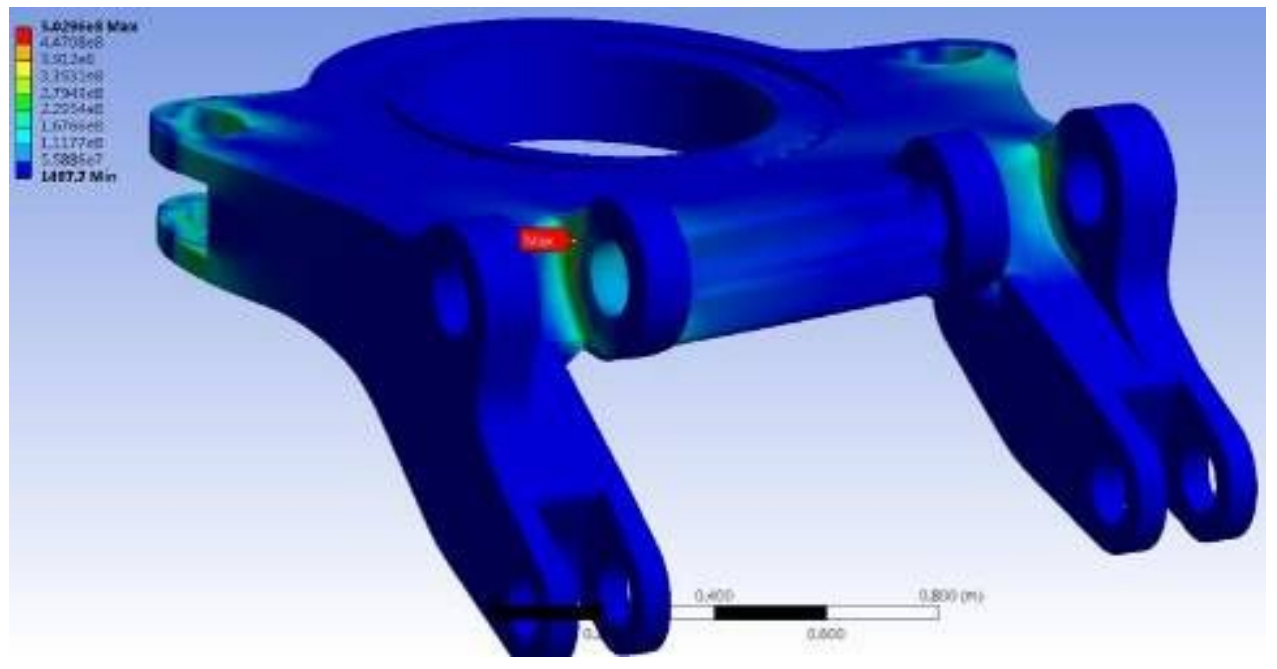

Figure 13

Stress cloud of rotary table 


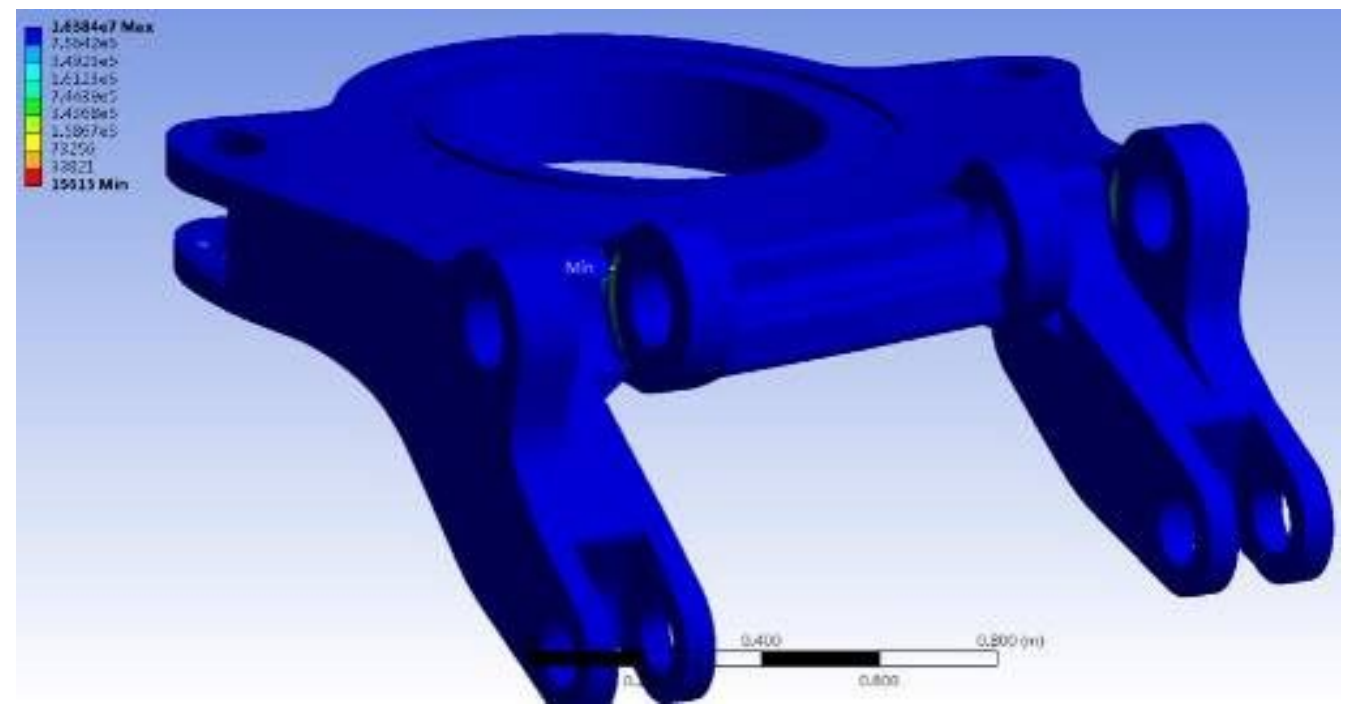

Figure 14

Stress cloud of rotary table from fatigue analysis using AWE

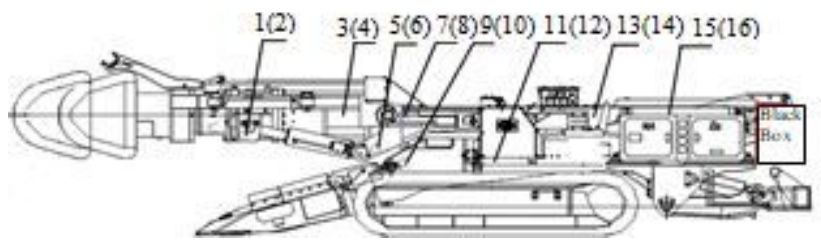

Figure 15

Schematic of the arrangement of measuring points in the roadheader

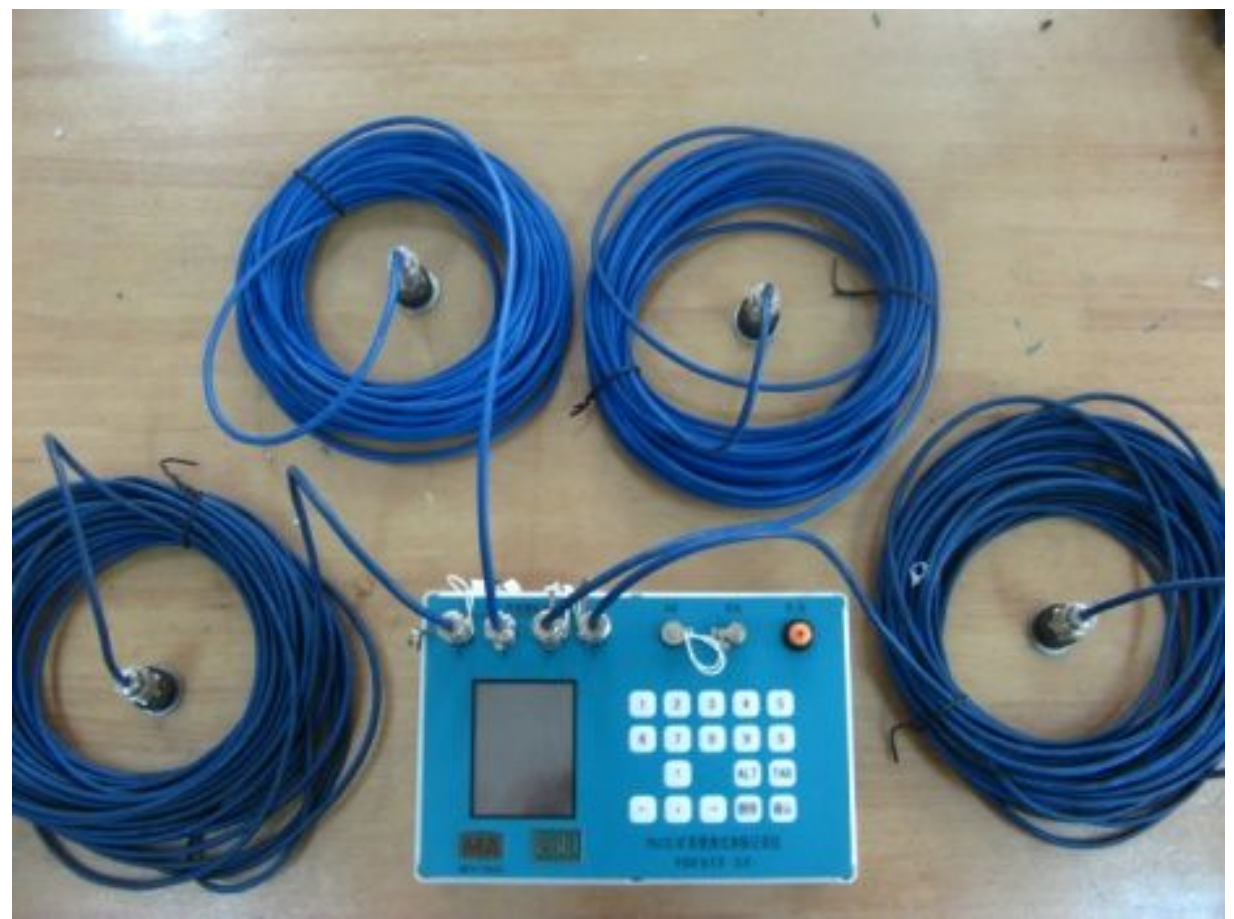

Figure 16 
Photograph of the sensor and the vibration meter coupling
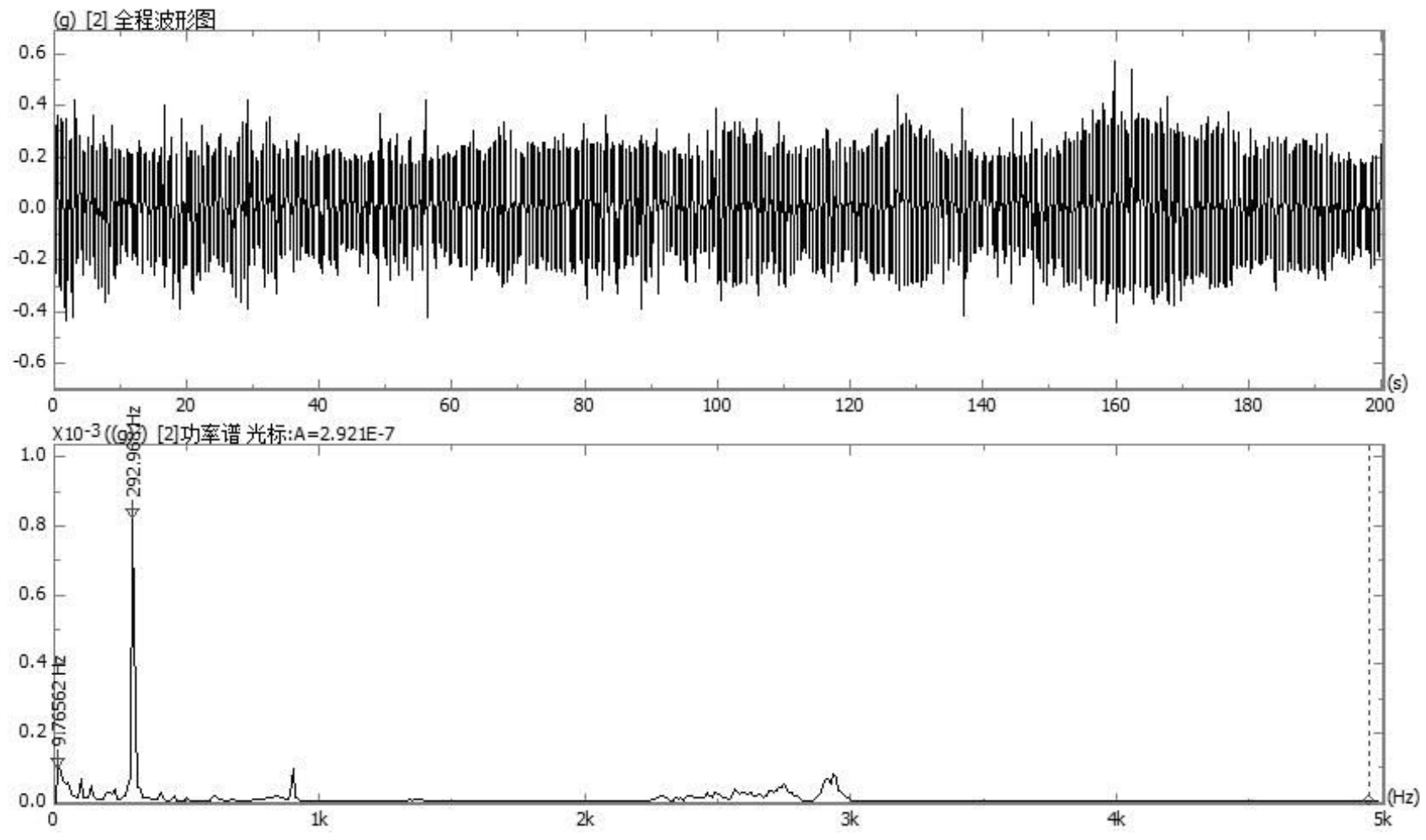

ID) $\mathbb{S P}$

自谱 - FFT分析

----数据参数----

试验名: 3955

试验号: 2

则点数目: 1

----分析慈数----

形式: 功率谱

SF : $10 \mathrm{kHz}$

$\mathrm{AF}$ : $5000 \mathrm{~Hz}$

dt: $100 \mathrm{us}$

df: $9.76563 \mathrm{~Hz}$

FFT 点数: 1024

谱线条数: 512

加窗：矩形窗

---平均分析---

方式: 线性平均

重叠: 0

平均: 1954 次

----频谱光标----

Hc: 509

f : $4960.94 \mathrm{~Hz}$

2015-04-12 $16: 19: 00$

\section{Figure 17}

Vibration frequency spectrum of the upper part of rotary table

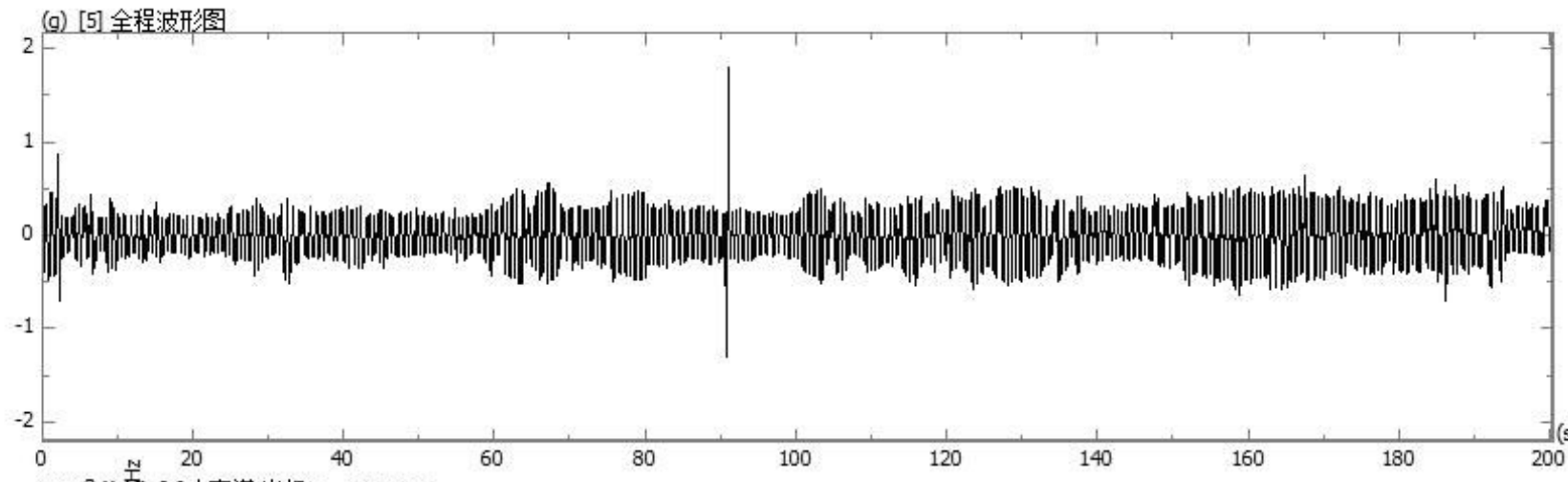

ID) $\mathbb{A S T P}$

自谱 - FFT分析

----数据参数----

试验名: 3955

试验号: 2

测点数目: 1

----分析参数----

形式: 功率谱

$\mathrm{SF}$ : $10 \mathrm{kHz}$

$\mathrm{AF}: 5000 \mathrm{~Hz}$

$\mathrm{dt}: 100 \mathrm{us}$ df: $9.76563 \mathrm{~Hz}$ FFT 点数: 1024 谱线条数: 512

加窗：矩形窗

----平均分析---

方式: 线性平均

重叠: 0

平均: 1954 次

----频谱光标----

Hc: 511

f : $4980.47 \mathrm{~Hz}$

Figure 18 


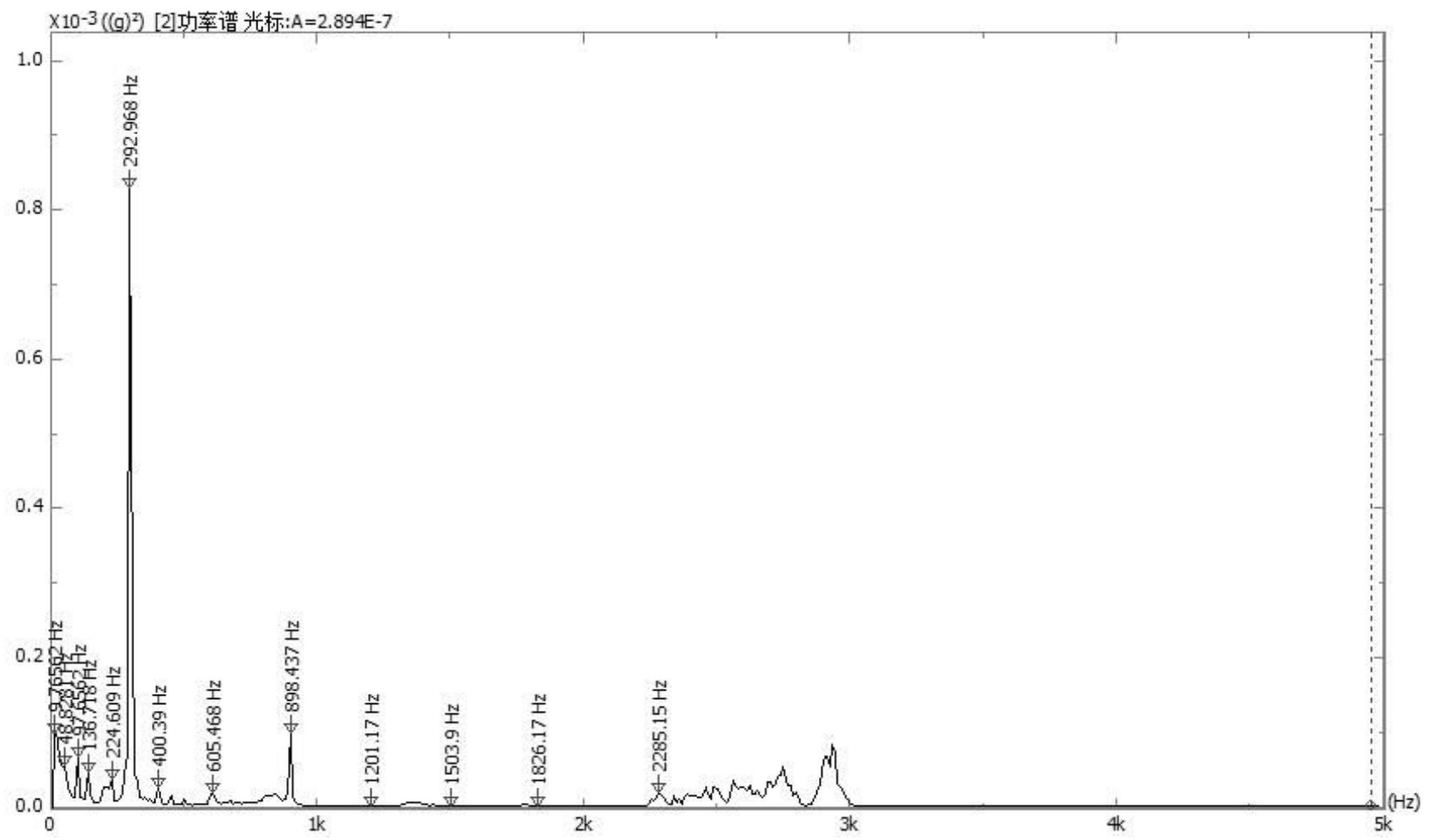

10) $A S]$

自谱 - FFT分析

----数据参数----

试验名: 3955

试验号: 2

测点数目: 1

----分析参数----

形式: 功率谱

SF: $10 \mathrm{kHz}$

AF: $5000 \mathrm{~Hz}$

dt: 100 us

df: $9.76563 \mathrm{~Hz}$

FFT 点数: 1024

谱线条数： 512

加窗：矩形窗

----平均分析----

方式: 线性平均

重叠: 0

平均: 1954 次

----频谱光标----

Hc: 510

f : $4970.7 \mathrm{~Hz}$

2015-04-11

19:43:05

\section{Figure 19}

Frequency diagram of rotary table vibration 